\title{
Tracking Down the Business Cycle: A Dynamic Factor Model For Germany 1820-1913
}

\author{
Samad Sarferaz* \\ Martin Uebele**
}

$\frac{v}{a}$

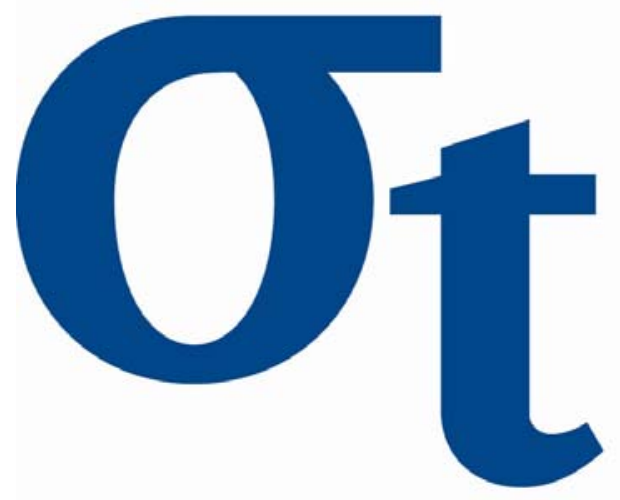

9)

寸

6

* Humboldt-Universität zu Berlin, Germany

** University of Warwick und Humboldt-Universität zu Berlin, Germany

This research was supported by the Deutsche Forschungsgemeinschaft through the SFB 649 "Economic Risk".

http://sfb649. wiwi.hu-berlin.de ISSN 1860-5664 


\title{
Tracking Down the Business Cycle: A Dynamic Factor Model For Germany 1820-1913*
}

\author{
Samad Sarferaz ${ }^{\dagger} \quad$ Martin Uebele ${ }^{\ddagger}$
}

First draft: May 12, 2005

This version: July 6, 2007

\begin{abstract}
We use a Bayesian dynamic factor model to measure Germany's pre World War I economic activity. The procedure makes better use of existing time series data than historical national accounting. To investigate industrialization we propose to look at comovement between sectors. We find that Germany's industrial sector developed earlier than stated in the literature, since after the 1860s agricultural time series do not comove with the business cycle anymore. Also, the bulk of comovement between 1820 and 1913 can be traced back to five out of 18 series representing industrial production, investment and demand for industrial inputs. Our factor is impressingly confirmed by a stock price index, leading the factor by 1-2 years. We also find evidence for early market integration in the 1820s and 1830s. Our business cycle dating aims to resolve the debate on German business cycle history. Given the often unsatisfactory quality of national accounting data for the 19th century we show the advantage of dynamic factor models in making efficient use of rare historical time series.
\end{abstract}

Keywords: Business Cycle Chronology; Imperial Germany; Dynamic Factor Models; Industrialization

JEL codes: E32, C11, C32, N13

${ }^{*}$ We are indebted to Albrecht Ritschl for many discussions and careful readings, and grateful for helpful advice to Pooyan Amir Ahmadi, Stephen Broadberry, Michael C. Burda, Carsten Burhop, Nicholas Crafts, Bartosz Mackowiak, Emanuel Mönch, Wolfgang Reichmuth, Oliver Volckart, Mirko Wiederholt, Nikolaus Wolf, and conference and seminar participants. Generous support is acknowledged from the Deutsche Forschungsgemeinschaft through SFB 649 "Economic Risk", Humboldt University of Berlin, and from the Marie Curie Research Training Network "Unifying the European Experience". An earlier version of this paper was awarded the 2006 New Researcher Prize of the Economic History Society.

${ }^{\dagger}$ Humboldt University of Berlin, sarferaz@wiwi.hu-berlin.de

${ }_{\ddagger}^{\ddagger}$ University of Warwick and Humboldt University of Berlin, m. uebele@warwick.ac.uk 


\section{Contents}

1 Introduction $\quad 2$

2 Model Setup and Estimation $\quad 4$

3 Two Data Sets 5

4 Research Design $\quad 6$

4.1 Real and Nominal Time Series . . . . . . . . . . . . . . . . . 6

4.2 Filtering and Standardization . . . . . . . . . . . . . . . . . . . . 7

4.3 Robustness Checks . . . . . . . . . . . . . . . . . 7

4.4 Convergence, Model Parameters, Subsets . . . . . . . . . . . . 8

$\begin{array}{lll}5 & \text { Results } & 8\end{array}$

5.1 The Transition from Agriculture to Industry . . . . . . . . . . . . . . 9

5.1 .193 series, $1840-1880 \ldots \ldots \ldots . \ldots \ldots$

5.1 .218 series, $1820-1913 \ldots \ldots \ldots \ldots$

5.2 Integration of the German Economy before 1850 . . . . . . . . . . . . 11

5.3 Business Cycle Chronology in Light of the Literature . . . . . . . . . 12

6 Conclusion $\quad 14$

$\begin{array}{llr}7 & \text { Appendix } & 20\end{array}$ 


\section{Introduction}

The empirical study of business cycles is very data intensive. While today statistical bureaus, research institutes and other organizations produce endless streams of relevant data, back in the 19th century statistics was a brand new field and statistical offices were established only quite late in the industrializing nations (see Tooze (2001) for the German case). Moreover, the first national accounts in the sense of a well defined measure of a nation's economic output and income were only introduced in the interwar period. In the US, for instance, the official annual national income and product accounts started only in 1929. In Germany, the Statistical office (Statistisches Reichsamt) began reporting national income on an annual basis in 1925. Official product and expenditure accounts are only available starting in 1950 for West Germany. All we know about national accounts before World War 1 therefore rests on backward-looking reconstructions by later researchers. In Germany, retrospective calculations of national income back to 1890 were presented by the Statistisches Reichsamt (1932), and an attempt to construct an index of industrial production was made by the semi-offical Institut für Konjunkturforschung in 1933, see Wagenführ (1933). Reconstruction of historical product accounts for the U.S. goes back to Kuznets $(1937,1941,1946)$. His work initiated a large flow of work on reconstructed national accounts, which has dominated the macroeconomic history literature for decades. The main problem facing this research has been the lack of data, which were collected only incompletely by contemporary researchers, and in most cases could only partly be recovered by later researchers. As a consequence, results often rely heavily on extrapolations from very few benchmarks. Consequently, they tend to differ widely across researchers in terms of business cycle turning points, volatility, or even fundamental growth trends ${ }^{2}$ In this paper, we offer an alternative way to obtain evidence on macroeconomic aggregates from the prenational accounting period. It relies on the NBER business cycle project of Burns and Mitchell (1946), whose philosophy was to collect a large number of disaggregate time series from all sectors of the economy to infer business cycle dynamics.

Modern statistical techniques provide a way to overcome the practical problem that Burns and Mitchell faced, the aggregation of information from the many indicator series. Triggered by the work of Stock and W. (1989), factor analysis has emerged as an efficient way of providing this information aggregation. In all cases, the underlying idea is the same: individuals, as well as policy makers, regularly observe a large number of highly disaggregate indicators and base their decisions on them. Consequently, a statistical aggregation procedure that uses the information content in these series efficiently should beat national accounts in determining business cycle turning points, forecasting, as well as in monetary policy analysis. Indeed, factor analysis as a means of information aggregation has become quite influential in these areas.

Our contribution is to take the same philosophy back to historical data, were

\footnotetext{
${ }^{2}$ For the US case, the debate unfolds in Balke and Gordon (1989) and Romer (1989), while reworks of UK's national accounts appeared by Crafts (1985) and Feinstein (1972), among others. For Germany, Burhop and Wolff (2005) and Ritschl and Uebele (forthcoming) provide an overview of the revisions to Hoffmann's (1965) national account estimates.
} 
the problem of missing or poor aggregate data is of specific urgency. Furthermore, we propose ways to make inference about structural change and spatial market integration, thereby extending dynamic factor model's natural domain of dating the business cycle. We do so by relying on the central argument of the dynamic factor literature, the comovement between large amounts of sectoral time series.

We believe the way we use dynamic factor models in a rare data environment may be helpful in other fields of historical research. It also has obvious applications in developing countries that do not produce data of sufficient quality and frequency.

Taking Germany as a case study is interesting, because there exist four different national accounting estimates, all differing considerably. That is why the timing of industrialization is an unresolved matter in the German case. Germany is regarded to be an industrial later comer, based on reconstructed national accounts (Hoffmann 1965, Gerschenkron 1962). Disaggregate time series evidence has been argued to suggest an earlier transition (Spree 1977). However, the disaggregate evidence has not been studied with rigorous statistical methods (Spree 1978, Spree 1977). In fact, existing studies disagree on the timing of Germany's industrialization (Grabas 1992, Spree 1978, Spree 1977, Spiethoff 1955, Burns and Mitchell 1946), and were mainly ad-hoc interpretations of the raw data. In contrast, we employ a formal method, a single dynamic factor model (DFM) estimated with Bayesian methods described in Kim and Nelson (1999). The latent single factor captures the notion of Burns and Mitchell's (1946) common business cycle in a formal way. The literature originated in the works of Sargent and Sims (1977) and Geweke (1977).

The data consist of a small set of 18 time series ranging from 1820 to 1913, and a large set of 265 time series covering 1840 to 1880, which includes the smaller data set (Spree 1978, Spree 1977). Both sets cover many aspects of the German economy, such as production, trade, investment, prices and money supply.

We obtain evidence for an earlier transition from agriculture to industry than historical national accounting suggests (Hoffmann 1965). Germany is regarded as a late industrializer in the classical contribution by Gerschenkron (1962). The weights the methodology assigns to the individual time series show us that the factor for 1820-1913 is mainly driven by industry. However, when we restrict the data analysis to the first half of the century we can show that agriculture played a dominant role during that period.

This evidence is further substantiated by obtaining factors for sectoral subsets of the dataset separately. The subfactor for agriculture is procyclical and coincident with the overall economy until about 1860, but becomes countercyclical during the 1860s. The subfactor for industry is procyclical and coincident already in the 1840s, but at that time does not dominate the business cycle yet.

We observe comovement between different regions and industries even before 1840. Given Germany's late political unification, this evidence for economic integration is astonishing. Before its unification in 1871, it consisted of a patchwork of kingdoms, duchies, and other autonomous states. Tariff borders within Germany were lowered step by step and finally disappeared with the Zollverein of 1834, and railway construction began in 1835. The comovement found here coincides or even predates those events.

Another aspect where national accounts and time series evidence disagree are 
the turning points of the business cycle. The economy fluctuated more regularly than evidence from historical national accounts suggests (Hoffmann 1965, Burhop and Wolff 2005). Measured between lower turning points, the mean duration of a cycle was 8.5 years, with a standard deviation of only 1.25 years.

Concerning Germany's business cycle history, we do find clear evidence for the "Gründerzeit" or startup boom of the early 1870s, which has often been described as a remarkably prosperous period. The richly decorated townhouses built in that era still influence strongly the conventional wisdom about these first years of Bismarck's German Empire. ${ }^{3}$ Yet there is the claim that spurious net national product data may have incorrectly contributed to that notion (Burhop and Wolff 2005). This discussion touches an important part of German history. Was the foundation of the German nation state really accompanied by a broadly based economic upturn? Our latent factor peaks in 1873, and it covers a wide array of industries. Indeed, construction can be identified as one of the main driving forces. It seems that the public opinion in this case needs not to be corrected.

The robustness of our factor is impressively confirmed by evidence from financial markets. We examine the comovement between a stock market index which includes the 30 largest German companies and is independent of the factor. We find that the index almost perfectly tracks the cyclical behavior of the factor and precedes it by $1-2$ years. $^{4}$

Summing up, the main contribution of this paper is to introduce Bayesian estimated dynamic factor models into the historical business cycle literature and, by doing that, complement the historical national accounting approach. We propose methods to analyze sectoral transition and market integration, based on comovement. The findings support our approach.

In the following we will outline the Bayesian factor model and its estimation, present the data, and finally discuss the results in detail.

\section{Model Setup and Estimation}

Dynamic factor models (henceforth: DFMs) in the vein of Sargent and Sims (1977), Geweke (1977) and Stock and W. (1989) posit that a given panel data set can be divided into a latent common component, which captures the comovements of the cross section, and a variable-specific idiosyncratic component. These models imply that macroeconomic activity is driven by a few latent driving forces, which can be represented by the estimation of the dynamic factors. A Bayesian approach to DFMs is provided by Otrok and Whiteman (1998) and Kim and Nelson (1999). We follow the latter approach in this paper.

Our data set consists of individual time series $y_{i, t}$ for $i=1, \ldots, N$ and $t=$ $1, \ldots, T$, with $N$ and $T$ representing the total number of cross-section variables and the length of the time series, respectively. The DFM assumes this dataset can be

\footnotetext{
${ }^{3}$ On the history of the German Empire see Wehler (1985) and Stern (1977).

${ }^{4}$ This is well in line with the predictions of capital market theory, see for example Cochrane (2001) or Campbell, Lo, and MacKinlay (1997).
} 
described with the following equations:

$$
y_{i, t}=\lambda_{i} f_{t}+u_{i, t},
$$

where $f_{t}$ represent the latent factor or common component, $\lambda_{i}$ is the factor loading or coefficient linking the common factor to the $i$ th variable, and where $u_{i, t}$ is the variable-specific idiosyncratic component. For the factor we assume an AR(q) process:

$$
f_{t}=\phi_{1} f_{t-1}+\phi_{2} f_{t-2}+\ldots+\phi_{q} f_{t-q}+v_{t} .
$$

The law of motion for the idiosyncratic shock $u_{i, t}$ is expressed as an $\mathrm{AR}(\mathrm{p})$ process:

$$
u_{i, t}=\theta_{1} u_{i, t-1}+\theta_{2} u_{i, t-2}+\ldots+\theta_{p} u_{i, t-p}+\xi_{i, t} .
$$

The disturbances $\xi_{i, t}$ and $v_{t}$ are both i.i.d. normal. The $\xi_{i, t}$ 's are independent across variables and are not correlated with $v_{t}$ at all leads and lags.

Two indeterminacies appear in this setup, which require additional identifying assumptions. First, there is a the scale indeterminacy, which can be pinned down by setting the variance of the factor innovations $v_{t}$ equal to a constant. ${ }^{5}$ Second, there is the sign indeterminacy of the factor loadings $\lambda_{i}$ and the factor $f_{t}$. To solve this problem we restrict one of the factor loadings to be positive (Geweke and Zhou 1996).

The model can be estimated via Gibbs sampling. This procedure enables the researcher to draw from nonstandard distributions, by splitting them up into several standard conditional distributions. In our case, the estimation procedure is subdivided into two blocks: first, the parameters of the model $\left(\phi_{s}, \theta_{r}, \lambda_{i}\right)$ for $s=1, \ldots, q$ and $r=1, \ldots, p$ are calculated, applying the methods described in Kim and Nelson (1999). Second, conditional on the estimated values of the first block, the factor $f_{t}$ is computed by applying the Kim and Nelson (1999) approach, using the Carter and Kohn (1994) algorithm. After the estimation of the second block, we start the next iteration step again at the first block, conditioning on the previous iteration step. It can be shown that the conditional posterior distributions converge to the joint posterior distribution at an exponential rate as the number of iteration steps goes to infinity (Geman and Geman 1984).

Finally, we assume a prior on the parameters of the model as in Kose, Otrok, and Whiteman (2003).

\section{Two Data Sets}

Spree (1978) analyzes 18 annual time series for the period 1820-1913. The series span a wide range of economics including prices, production, productivity, consumption, investment and demographics (Table 3). All series cover the area of the German Empire as it existed from 1871 on without Alsace-Lorraine (if not stated otherwise). Most series are spliced together from different sources. For the second half of the 19th century, there is sufficient data for most of the German regions. For the preceding decades the series were often extrapolated backwards using regional data. An overview of the sources can be found in the appendix.

\footnotetext{
${ }^{5}$ Amongst others, Sargent and Sims (1977).
} 
We use the longer data set as it is. Only for the construction of the agricultural subfactor, the agricultural production series is substituted by four regional series for wheat and potato production (Helling 1977).

Spree (1977) also provides a larger data set, consisting of 265 time series for the period 1840-1880. It is an extremely rich data set, comparable in scale maybe only to Hoffmann (1965). About 50 of the 265 series rely on Hoffmann (1965), 23 on Spiethoff (1955), 22 on Jacobs and Richter (1935), 20 on Borries (1970), 18 on Kirchhain (1971), and 11 on Fremdling (1975). Additionally, we draw on a large amount of scattered quantitative and qualitative literature, and thus obtain a dataset that covers a large proportion of activity in the German economy. ${ }^{6}$

The larger data set, however, has to be reduced due to a number of reasons. Since some single data points are missing, we cannot use the complete data set, as our method needs balanced panels. We also discard a large number of other series, mainly because of redundancies. For example, consumption series can be neglected if imports, exports and production are given for the same commodity. Furthermore, many production series are included both in volumes and in values, of which we use only the volume information. Moreover, we exclude stock market information in order to use stock market indices to check for robustness. We add 18 time series from Spree (1978) that are not part of the large data set in Spree (1977). The sample we work with finally consists of 93 series (Table 3, column 3).

\section{Research Design}

In this section we motivate our research strategy. We start out by discussing why we use both real and nominal time series. Then we explain our choices regarding the data sets as well as data transformation and filtering. We go on with laying out how we check for representativeness of the data sets. Finally we show how we intend to separate sectoral subsets and how we use $R^{2}$ for our argument.

\subsection{Real and Nominal Time Series}

Economists and economic historians are usually interested in real economic activity. For the estimation of our one-factor model, however, we use both real and monetary time series. We are aware of potential misinterpretations, but we understand this approach in the tradition of the diffusion index literature as established by Burns and Mitchell (1946). Looking at the comovement of an indefinite number of time series of unspecified character is a relatively agnostic approach. We do this because real historical time series are often badly measured. Nominal series, on the other hand, contain information about the relation of supply and demand that we do not want to discard. This means that in the first step of the analysis, we do not differentiate between real and nominal series. In a similar fashion, we do not distinguish between agricultural or industrial time series, public and private sector data, or any other economic structure that could be imposed on the data. One factor models of the

\footnotetext{
${ }^{6}$ The exact sources for every series can be obtained from the authors or downloaded at www.histat.gesis.org.
} 
economy are known for their strong power in dating business cycles (see Stock and Watson (2005). Other successful applications of these models include analysis of the frequency content and of variations in volatility (see for example Del Negro and Otrok (2005) and Ritschl, Sarferaz, and Uebele (2007)).

This clearly differentiates our approach from the business cycle literature that draws on historical national accounts. National accounting proceeds by aggregating data under strong assumptions about their economic structure. For example, sectoral weights are needed to add up output indices from agriculture, industry and service. However, it is often empirically difficult or even impossible to identify the correct weights of the sectors (Hoppit 1990).

\subsection{Filtering and Standardization}

To eliminate trends, we try different filters in order to extract the business cycle component from the logarithmized data. The remaining business cycle component is then z-standardized. We employ the Hodrick-Prescott filter with a $\lambda$ of 6.25 (according to Ravn and Uhlig (2002)) and the more traditional $\lambda=100$. Alternatively we use the modified Baxter-King filter (Baxter and King 1999, Woitek 1998) and the Christiano-Fitzgerald filter (Christiano and Fitzgerald 2003), which are band pass filters that eliminate cycles shorter than 2 and longer than 15 years. The main results are robust to variations of the filter method. ${ }^{7}$ Therefore we report only the Hodrick-Prescott filtered data, which guarantees broad comparability. ${ }^{8}$

\subsection{Robustness Checks}

We propose two robustness checks concerning the choice of series for the smaller data set. We employ the same model to the larger data set of which the smaller constitutes a subset and plot the resulting factors against each other. Robustness is shown when both series appear to be similar. Given that the broader set consists of a large number of time series, this would be strong evidence for the relevance of the small data set.

A second robustness check was made in order to cover the period after 1880, where the large data set ends. For this we use stock market data. German stock markets developed vigorously after the Prussian Joint Stock Company Act of 1870 deregulated IPOs. In 1913 market, capitalization relative to GDP was 44\%, a level that in Germany was only reached again in the 1990s (Rajan and Zingales 2003), but not so much as to make the argument of considerable stock market capitalization invalid. Various empirical studies confirm the necessary assumption of weak capital market efficiency (Baltzer and Kling 2003, Bittner 2005).

\footnotetext{
${ }^{7}$ As a fourth check we simply take the first differences of the series, still a widely used method in empirical research, but the one that causes the largest distortions in the business cycle component (see for example A'Hearn and Woitek (2001)).

${ }^{8}$ The full set of results can be requested from the authors.
} 


\subsection{Convergence, Model Parameters, Subsets}

Since we are making random draws from a chain of conditional distributions, we have to decide which draws to take in order to make sure that the factor estimates converge. From a total number of 30,000 draws for the factor we discard the first 6,000 as burn-in. In order to avoid serial correlation along the Markov chain, we only use every third draw and discard the rest. The remaining 8,000 we finally use for inference. We repeat the estimation using different starting values and verify the results are not sensitive to the choice of the starting values. Second, two subsets of the total set of draws are compared with each other. In all cases, the differences were almost invisible and are therefore not documented here.

As explained in Section 2 we can choose the order of the AR-representation of the factor $f_{t}$ as well as the idiosyncratic process $u_{i, t}$, i.e. $q$ and $p$, respectively. We experimented with different orders, and decided on $q=8$ and $p=1$. Alternative orders do not change the results considerably.

We divide the larger data set into subsets to identify the movement of certain sectors: 22 series make up for agriculture, for heavy industries we choose 31 series. Construction is represented by five series, textile industry by 29. (Table 3, columns $4-7)$.

In order to find arguments about when industrialization occurred, we divide the long data set in shorter pieces to look for variations in time. The broader data set we divide into cross sectional subsets and estimate separate factors. We calculate bivariate $R^{2}$ s, regressing each single series on the factor. This tells us how much of each series' variance can be explained by the factor. For the broad data set we summarize the $R^{2}$ s by industry, for the results for all series are shown. We produce bar graphs that show the $R^{2}$ s ordered by value.

\section{Results}

In this section we deal with the transition of Germany's economy from agriculture to industry, and discuss the case of integration even before 1850. The section concludes with a detailed discussion of our findings on German business cycle history in the light of the literature.

Before starting with the structural analysis let us start with the results of the robustness checks. As evident from Figure 1 both datasets overlap for the years of 1840-1880. The factors obtained from the two sets yield exactly the same business cycle turning points. The comparison to the stock market corroborates this result. Figure 1 (lower panel) shows the high degree of correlation between the stock market and the factor from the narrow data set. It also exhibits that the stock market is leading the factor. The strong resemblance of the factor and the stock price index should not be undervalued. The two data sets are independent from each other. Note also that a similar result has been obtained already in a previous study on Germany (Ritschl and Uebele forthcoming) using frequency-domain techniques. The result is perfectly in line with what capital market theory would predict, namely that the stock market should be procyclical and leading. To our knowledge, there are few empirical studies about the predictive power of stock prices that confirm the 
theory so clearly, and even less for the 19th century. This result can therefore not be stressed enough.

The factor for 1820-1913, estimated from a narrow set of series, but robust for checks against larger data sets, is shown in Figure $2 .^{9}$

\subsection{The Transition from Agriculture to Industry}

One of the main points of this paper is that we use our model to investigate structural transition. We do this by restricting the sample either in time, or across series, or both. We look at the factor itself, the factor loadings and at the $R^{2} s$, the explanatory power of the factor for each series. We first discuss the sectoral results from splitting up the large data set for 1840-1880. Then we look into the longitudinal subsets taken from the 1820-1913 data.

Table 1 about here.

\subsubsection{3 series, $1840-1880$}

The factor from the total set is represented as the heavy broken line in Figure 1 (upper panel). From the large data set we construct a subset for the agricultural sector that includes an index of net crop production, various price series and some agricultural trade figures. Figure 3 shows the agricultural factor.

It features a very dominant peak in 1847 and less prominent ones in 1855, 1862 and 1868 as well as two smaller peaks in 1873 and 1876. The peak in 1847 is both due to a massive increase in grain prices and production increases. The price peaks were not only observed in Germany, but all over Europe, the last European crisis of the type "ancienne" (Le Roy Ladurie 1974). Berger and Spoerer (2001, p. 303) report that due to crop failures in preceding years another bad harvest was expected but in fact Prussian grain production grew by about $120 \%$ compared to 1846 (Helling 1977, p. 227), which is reflected in the index of net crop production. Some authors however, do not recognize this surge in agricultural production. Borchardt (1976, p. 258) for example mentions solely the "catastrophical crop failure" and the "undescribable misery" of the years 1846 and 1847, but not the production increase, maybe because prices did not fall. Since both prices and production had a cyclical peak, 1847 was surely a very good year for agricultural producers in Prussia and similar in Bavaria, Saxony and Wurttemberg (Helling 1977, p. 229).

Figure 3 about here.

Consumers however had to bear the high prices dictated by world markets and previous bad harvests. According to Berger and Spoerer (2001, p. 303) this caused a severe downward pressure on real wages and spilled over to the industrial sector

\footnotetext{
${ }^{9}$ The scale of the factor in Figure 2 is not interpretable as explained in Section 2. In Figures 11 and 12, however, the factor is calibrated to the standard deviation of Burhop and Wolff's (2005) "Compromise" NNP estimate for comparison purposes.
} 
in 1848. Since a major share of real wages was squeezed to close or even below subsistence level the consumption of manufactured goods declined as a consequence. According to Berger and Spoerer investment suffered from rising interest rates as credit demand increased (p. 305). Thus 1847, the "good year" in terms of our factor, was a considerably bad year for at least industrial workers and may have caused the subsequent economic downturn.

The literature agrees that Germany up to mid century was still a largely agricultural economy (Borchardt 1976, pp. 258). In our framework this is reflected in comovement of the agricultural subfactor with the overall factor. However this changed quickly in the following decades. Already in the 1860s the upturn shown by the overall factor is matched by a downturn of the agricultural subfactor. Thus, different from 20 years earlier, there is no evidence anymore of a spill over from agriculture to industry.

However, historical national accounting tells us that until 1890 agriculture remains the sector that contributes more to national income than any other single sector, a year when it employs $42 \%$ of the workforce (Hoffmann 1965, pp. 33,35). Borchardt (1976, pp. 255,259) speaks of an economy in transition before 1870 and attributes the beginning to the 1840s, but acknowledges "strong influences of agricultural cycles on the economic aggregates in the 1850s and 1860s". Similarly Spree (1978, pp. 101) explains the upturn until 1847 partly as driven by industry, and the "Gründerzeit"-boom 1873 entirely as a "modern" cycle. Comparing our agricultural factor with the overall however we shift the completion of the transition by a decade backwards: The boom in the 1860s already was independent of agriculture.

Table 1 about here.

\subsubsection{8 series, $1820-1913$}

We now turn to the investigation of the 1820-1913 data set. It consists of 18 time series from various sectors, whereas above we looked at a broader and shorter data set. The evidence stems from looking at the factor loadings assigned to the individual series. They show that the factor loads heavily on five out of 18 series (Table 1, column 5 and Figure 5): raw materials' wholesale prices, Prussian iron and coal production, import prices for iron, and Berlin and Hamburg discount rates. The picture becomes even clearer if we look at $R^{2}$, the share of variance explained by the factor (Table 1, column 6 and Figure 6). While 30\% to $70 \%$ percent of the variances of these five series are explained, none of the other series' variance is explained by more than $13 \%$. This reveals an overwhelming emphasis of the model on the industrial sector and investment demand.

Figure 5 about here.

We now look at certain subperiods of the 19th century, extending the data from earlier to later periods. First we compare the $R^{2} s$ for $1820-50$ of to a subset for the years 1820-1880. Among the 1820-50 series, we notice comovement across sectors (Figure 8) as expressed in the relatively high $R^{2}$ for may series. Eight out of 18 se- 
ries have $20 \%$ percent of their variance explained by the factor, five of them are not heavy industry series. Adding information of the next 30 years changes the picture considerably: Now four series' are explained well by the factor (at a $20 \%$ threshold) and all of them represent heavy industries (Figure 10). In contrast, including the time up to WW1 does not change the explanatory power nor the factor loadings in any meaningful way anymore (Figure 6).

Figure 8, Figure 10 and Figure 6 about here.

Summing up, both the cross-sectional and the inter-period comparison tell the same story: a strong positive correlation between agriculture and the overall economy up to mid-century, then decreasing, while heavy industry - playing already a role before 1850 - becomes dominant not later than 1880 .

\subsection{Integration of the German Economy before 1850}

Figure 2 shows the latent factor calculated from the smaller data set. It features an upturn in 1825 and a double peak in 1836 and 1839. A longitudinal subset isolates the dynamics between 1820 and 1850. We split up the index of agricultural production into its main regional components for Prussia, Saxony, Württemberg and Bavaria to allow for potential geographical variation (data from Helling (1977)). Interestingly, in Figure 8 we observe comovement in terms of $R^{2}$ across regional series (e.g. Hamburg/Berlin interest rate, Prussian pig iron, Bavarian crops), which also comove with supraregional aggregates (population, cotton investment, wholesale prices raw materials). The regional comovement indicates that economic integration was already under way.

Given Germany's scattered political landscape and the beginning of railway transport only in the mid-1830s this is an astonishing finding. However, Craig and Fisher (2000, p. 212) regard the Zollverein and the railroad as generally overrated in the discussion of German 19th century economic integration. They suggest that political integration, the Zollverein, and the railroad were not the cause, but rather the consequence of economic integration and growth. In line with this argument Kaufhold (1993, p. 577) reports that railroads were publicly discussed early in the 1820s in Germany. Bairoch (1982) accordingly reports substantial growth rates for Germany in between 1800 and 1830. Another argument follows from Berger and Spoerer (2001), who compare the integration of Prussian and European grain markets. Drawing on Fremdling and Hohorst (1979) they take the Prussian coefficient of variation starting in 1820 as a benchmark for grain market integration and observe that the European markets converge to that level by the early 1840s (Berger and Spoerer (2001, p. 300).

Figure 2 about here. 


\subsection{Business Cycle Chronology in Light of the Literature}

Figure 2 shows the latent factor calculated from the smaller data set. Note that the cyclical swings occur very regularly over the whole period. The average cycle duration was 8.5 years with a standard deviation of 1.25 years. An overview of the business cycle chronologies can be found in Table 7 .

Table 7 about here.

The 1840s We confirm most of the frequently mentioned economic swings in 19th century Germany: the latent factor features the downturn in 1848 that could be felt throughout the continent and was accompanied by political turmoil in many European countries. The literature agrees without exception on the downturn, but offers varying explanations: Kaufhold (1993, p. 577) emphasizes a deceleration in railroad investment after the first railroad boom in the 1830s and 40s. On the other hand, Berger and Spoerer (2001) relate the revolutions and the economic downturn to bad harvests in the preceding years. Their argument and the relation between industry and agriculture will be dealt with in more detail further below.

The 1850s Borchardt (1976, p. 260) reports an upswing in the early 1850s, with an upper turning point in 1857. Our factor confirms this. According to Spree (1977, p. 343), strong investment in heavy industry was a major contributor to this boom, but then credit shortages occurred after banking panics in the US and stock market crashes shook investors' confidence. Thus the downturn after the peak in 1857 was not a uniquely German experience, but was felt worldwide. Still, neither in scale nor in scope was it comparable to the Great Depression after 1929 (Borchardt 1976, p. 261).

The 1860s Differently from most of the literature, we obtain a clear boom in 1864, a period that is commonly seen as mainly characterized by Prussia's wars in 1864 and 1866. Interestingly, the textile industry has a strong peak in 1864, suggesting the possibility of a causal relationship (Figure 4). One aspect of the peak in our factor may be high cotton prices that can most likely be traced back to the production decline in the war-torn United States (Spree 1977, p. 346), a fact that might explain the notion of a rather "peculiar" textile industry cycle (Borchardt 1976, p. 262).

Spree (1977, p.347) reports positive growth rates in heavy industry in the early 1860s. This means he disregards the widespread opinion of a lower turning point in 1866 as reported for example in Borchardt (1976, p.262). Borchardt's view of a crisis around 1866 assumes a subsequent upturn starting not later than 1869. In contrast, our factor peaks in 1864 and then experiences a steady downturn until 1870, when it finally starts to grow again. This strongly confirms Spree's (1977) tacit revision of the traditional view on the 1860s' business cycle. Our result is partly confirmed by Burhop and Wolff (2005) who find the 1864 boom, but also a bust in 1867, which we can not find (Figure 11, "Compromise").

The 1870s Our factor's peak in 1873 corresponds to the Gründerzeit startup boom after the foundation of the Empire of 1871 and the victory over France. The subsequent steep decline, also shown by our factor, is known as the Gründerkrise, or startup bust. To our knowledge, with the exception of Burhop and Wolff (2005), 
neither the contemporary nor the recent literature has ever generally questioned the existence of this boom-bust pattern. Borchardt (1976, p. 205), drawing on Hoffmann's (1965) "Expenditure" NNP estimate, acknowledges "above average growth in the years 1870-74 and stagnation up to 1880 (Figure 12). He also reports pig iron consumption, a traditional investment indicator, to have increased between 1868 and 1873 by $140 \%$ (p. 262). The literature also generally agrees on the subsequent period of depression. Fischer (1985, p. 392), using Hoffmann's (1965) "Output" NNP estimate, calls it a "severe recession", while Borchardt (1976, p. 265) emphasizes its unusual duration and its "unparalleled" increase in unemployment (Figure 11).

The doubts about this business cycle pattern were expressed by Burhop and Wolff (2005). As Ritschl and Uebele (forthcoming) point out, their findings can be explained by the deflation procedure. Burhop and Wolff's (2005) estimate is a weighted average of four real NNP series they take from Hoffmann (1965) and Hoffmann and Müller (1959). Their nominal NNP estimates show a different cyclical behavior than the deflated series due to the cyclical information contained in the price index. This effect is particularly strong with the series by Hoffmann and Müller (1959), since nominally it is very smooth, and thus the fluctuations of the price index translate almost unchanged into the deflated series. This causes a downturn in the early 1870s in Burhop and Wolff's (2005) averaged NNP-measure, because Hoffmann and Müller's (1959) series has a 50\% weight in it (Figure 12, "Taxes").

Burhop (2005) revised Hoffmann's (1965) industrial production figures for pre WWI Germany. He confirms the boom of the early 1870s, but finds it was narrow and mainly driven by construction. Our factor from the construction subset indeed has a pronounced peak in 1873, and thus confirms Burhop's (2005) finding (Figure 3 ). Still, other sectors were involved in the upswing as well. The factor calculated from a subset for heavy industries peaks as well in 1873 (Figure 4).

The 1880s During the 1880s we identify a recession with a lower turning point in 1886. This trough is also reported by Borchardt (1976, p. 267) on the basis of Hoffmann's (1965) "Output" national expenditure estimate (Figure 11). Burns and Mitchell (1946, p. 79) had already posited the existence of a slump in that year using disaggregated quarterly and monthly series. Burhop and Wolff (2005) also find a minor recession in 1886 (Figure 11).

The 1890s The subsequent 1890 upper turning point and the 1894 downturn of our factor can also be found in Burns and Mitchell (1946, p. 79), and Spiethoff (1955, pp. 123). Borchardt (1976, p. 267) identifies investment (especially housing investment) as one of the driving forces for this upturn. Burhop and Wolff (2005) as well as Craig and Fisher (1992) find the 1894 trough but additional ones in 1891 (Figure 11).

1900-1913 Based on the analysis of 171 monthly time series Grabas (1992) confirms the upper turning points of our factor in 1900 and 1907/8. Grabas and Burns and Mitchell (1946, pp. 78) use monthly data and report an upturn for Germany, France, Britain and the US for early 1907 and an immediate downturn late in 1908. Borchardt (1976, p. 269), based on NNP estimates, describes an upturn starting in 1903 until 1906/7, then transforming quickly into a crisis with the upturn following 1909/10. 
We find the same peak as Grabas (1992) and Borchardt (1976) in 1907, but a lower turning point as late as 1911, before the business climate eases again. Thus while there is agreement on the peak in 1907 and the downturn in 1911, we have no evidence for a short-lived cycle in between.

\section{Conclusion}

This paper has tracked down the German business cycle of the 19th century. Our approach rests on the pioneering work of Burns and Mitchell (1946) and recent developmemts in dynamic factor analysis. This method allows us to avoid the use of aggregate data and to replace it with statistical aggregation from a large number of disaggregate historical times series. This helps to relax the data constraints facing historical business cycle research. Since national accounting needs a predefined set of macroeconomic data, it cannot use many of the historical data series that exist. Instead, it has to fill gaps by approximations that have the potential to contaminate the other, well measured data. In contrast, factor analysis allows us to exploit the information content in a large num ber of existing historical time series, irrespective of whether they would sum up into meaningful national account aggregates. As an analytical tool we add the comparison of subsectors to investigate sectoral transition and market integration. Surprisingly strong confirmation for the method comes from comparison to the financial sector: a blue chip stock market index exhibits high correlation with our factor, and leads it by one year.

Our sectoral results suggest that industrialization influenced the German business cycle earlier than national accounts have suggested so far. Before 1850, all major sectors contributed evenly to the business cycle. Extending the analysis to the 1880s, we find that the business cycle was mainly driven by the industrial sector. Notably, agriculture began to move countercyclically in the $1860 \mathrm{~s}$. We believe this confirms Spree's $(1978,1977)$ notion of a common German business cycle that was influenced by industry already in the 1840s and clearly dominated by industry around 1880. We also find evidence for a common cycle that potentially reaches back until the 1820s. We show that this factor is representative for the whole economy. Thus we confirm the notion of an early common cycle featured in the convergence literature à la Craig and Fisher (2000).

For the period after the foundation of the Empire of 1871, we mostly confirm the traditional NBER chronology of Burns and Mitchell (1947). Importantly, we find strong evidence in favor of the "Gründerzeit" or startup boom in Germany after 1871, which had been called into question by Burhop and Wolff (2005). We also find little support for the shorter and less regular cyclical pattern suggested by the national account estimates of Hoffmann (1965).

The methods employed in this paper have a natural application to other industrializing economies where national account data were poor. Using factor analysis seems to us a promising alley of historical and applied business cycle research, and a convenient alternative to historical national accounting. 


\section{References}

A'Hearn, B., and U. Woitek (2001): "More Evidence on the Historical Properties of Business Cycles," Journal of Monetary Economics, 47, 321-346.

BAIRoch, P. (1982): "International Industrialization Levels from 1750 to 1980," Journal of European Economic History, 11(2).

Balke, N., And R. Gordon (1989): "The Estimation of Prewar Gross National Product: Methodology and New Evidence," Journal of Political Economy, 97, 38-92.

Baltzer, M., and G. Kling (2003): "Resiliency of the pre-World War I German stock exchange: evidence from a panel vector autoregression," Discussion paper, University of Tuebingen.

Baxter, M., And R. King (1999): "Measuring Business Cycles: Approximate Band-Pass Filters for Economic Time-Series," The Review of Economics and Statistics, 81, 575-593.

Berger, H., And M. Spoerer (2001): "Economic Crisis and the European Revolutions of 1848," Journal of Economic History, 61(2), 293-326.

Bittner, T. (2005): "An Event Study of the Rhenish-Westphalian Coal Syndicate," European Review of Economic History, 9(3), 337-364.

BorchardT, K. (1976): Wirtschaftliches Wachstum und Wechsellagen 1800 1914pp. 255-275. Ernst Klett.

Borries, B. V. (1970): Deutschlands Außenhandel 1836 bis 1856. G. Fischer.

Burhop, C. (2005): "Industrial Production in the German Empire, 1871-1913," Discussion Paper, University of Münster.

Burhop, C., And G. B. Wolff (2005): "A Compromise Estimate of Net National Product and the Business Cycle in Germany 1851-1913," Journal of Economic History, 65(3), 615-657.

Burns, A. F., And W. C. Mitchell (1946): Measuring Business Cycles. NBER.

Campbell, J. Y., A. W. Lo, and A. C. MacKinlay (1997): The Econometrics of Financial Markets. Princeton University Press.

Carter, C., and R. Kohn (1994): "On Gibbs Sampling for State Space Models," Biometrika, 81, 541-553.

Christiano, L. J., And T. J. Fitzgerald (2003): "The Band Pass Filter," International Economic Review, 44(2), 435-465.

Cochrane, J. H. (2001): Asset Pricing. Princeton University Press. 
Crafts, N. F. R. (1985): British Economic Growth During the Industrial Revolution. Oxford University Press.

Craig, L. A., And D. Fisher (1992): "Integration of the European Business Cycle: 1871-1910," Explorations in Economic History, 29(2), 144-168. (2000): The European Macroeconomy. Edward Elgar.

Del Negro, M., and C. Otrok (2005): "Dynamic Factor Models with TimeVarying Parameters," mimeo, 19.

Dieterici, C. F. W. (1931): Statistische Übersicht der wichtigen Gegenstände des Verkehrs und Verbrauchs im preussischen Staate und im deutschen Zollverbande in dem Zeitraume 1831 bis 1836.

Feinstein, C. H. (1972): National Income, Expenditure and Output of the United Kingdom, 1855-1965. Cambridge University Press.

FISCHER, W. (1985): Handbuch der Europäischen Wirtschafts- und Sozialgeschichtepp. 357-442, no. 5. Klett-Cotta.

Fremdling, R. (1975): Eisenbahnen und deutsches Wirtschaftswachstum 18401879. Ges. für Westfäl. Wirtschaftsgeschichte eV.

Fremdling, R., And G. Hohorst (1979): Industrialisierung und Raumchap. Marktintegration der preußischen Wirtschaft im 19. Jahrhundert, pp. 57-104. Klett-Cotta.

Gehrmann, F. (1913): Konkurse im Industrialisierungsprozeß Deutschlands, 18101913. Diss.

Geman, D., and S. Geman (1984): "Stochastic Relaxation, Gibbs Distributions, and the Bayesian Restoration of Images," IEEE Transactions on Pattern Analysis and Machine Intelligence, PAMI-6, 721-741.

Gerschenkron, A. (1962): Economic Backwardness in Historical Perspective: A Book of Essays. Belknap Press of Harvard University Press.

GeweKe, J. (1977): The Dynamic Factor Analysis of Economic Time SeriesLatent Variables in Socio-Economic Models. North-Holland.

Geweke, J., And G. Zhou (1996): "Measuring the price of the Arbitrage Pricing Theory," The Review of Financial Studies, 9(2).

Grabas, M. (1992): Konjunktur und Wachstum in Deutschland von 1895 bis 1914 (Schriften zur Wirtschafts- und Sozialgeschichte). Duncker und Humblot.

HeLling, G. (1965): "Berechnung eines Index der Agrarproduktion in Deutschland im 19. Jahrhundert," Jahrbuch für Wirtschaftsgeschichte, 4.

(1977): Nahrungsmittel-Produktion und Weltaußenhandel seit Anfang des 19. Jahrhunderts. Akademie-Verlag. 
Hoffmann, W. G. (1965): Das Wachstum der deutschen Wirtschaft seit der Mitte des 19. Jahrhunderts. Springer-Verlag.

Hoffmann, W. G., And J. G. Müller (1959): Das deutsche Volkseinkommen 1851-195\%. J. C. B. Mohr.

Holtfrerich, C.-L. (1973): Quantitative Wirtschaftsgeschichte des Ruhrkohlebergbaus im 19. Jahrhundert. Ges. für Westfäl. Wirtschaftsgeschichte eV.

Hoppit, J. (1990): "Counting the Industrial Revolution," Economic History Review, 18(2).

Jacobs, A., And H. Richter (1935): "Die Grosshandelspreise in Deutschland von 1792 bis 1934," Vierteljahrshefte zur Konjunkturforschung, (Sonderheft 37).

KAufHOLD, K. H. (1993): Handbuch der Europäischen Wirtschafts- und Sozialgeschichtepp. 523-588, no. 4. Klett-Cotta.

Kim, C. J., And C. R. Nelson (1999): State-space models with regime switching. MIT Press.

Kirchhain, G. (1971): Das Wachstum der deutschen Baumwollindustrie im 19. Jahrhundert. Ayer Publishing.

Kose, M. A., C. Otrok, and C. H. Whiteman (2003): "International Business Cycles: World, Region, and Country-Specific Factors," American Economic Review, 93(4), 1216-1239.

Kuznets, S. (1937): National Income and Capital Formation. 1919-1935: A Preliminary Report. National Bureau of Economic Research.

(1941): National Income and Its Composition, 1919-1938. National Bureau of Economic Research.

(1946): National Product Since 1869. National Bureau of Economic Research.

Le Roy Ladurie, E. (1974): The Peasants of Languedoc. University of Illinois Press.

Marchand, H. (1939): Säkularstatistik der deutschen Eisenindustrie, Schriften der volksirtschaftlichen Vereinigung im rheinisch-westfälischen Industriegebiet. Essener Verlagsanstalt.

MÜssig, E. (1920): "Eisen- und Kohlen-Konjunkturen seit 1870," Jahrbücher für Nationalökonomie und Statistik, 1920(4).

Otrok, C., And C. H. Whiteman (1998): "Bayesian Leading Indicators: Measuring and Predicting Economic Conditions in Iowa," International Economic Review, 39(4), 997-1014. 
Rajan, R. G., And L. Zingales (2003): "The Great Reversals: The Politics of Financial Development in the Twentieth Century," Journal of Financial Economics, $69,5-50$.

Ravn, M., And H. Uhlig (2002): "On Adjusting the HP-Filter for the Frequency of Observations," Review in Economic Studies, 69(2), 371-375.

Ritschl, A., S. Sarferaz, and M. Uebele (2007): "The U.S. Business Cycle, 1867-1995: Dynamic Factor Analysis vs. Reconstructed National Accounts," mimeo.

Ritschl, A., And M. Uebele (forthcoming): "Stock Markets and Business Cycle Comovement in Germany before World War I: Evidence from Spectral Analysis," Journal of Macroeconomics.

Romer, C. (1989): "The Prewar Business Cycle Reconsidered: New Estimates of Gross National Product, 1869-1908," Journal of Political Economy, 97(1), 1-37.

Sargent, T. J., And C. A. Sims (1977): Business cycle modeling without pretending to have too much a priori economic theory. Federal Reserve Bank of Minneapolis.

SoetBeer, A. (1886): Materialien zur Erläuterung der wirtschaftlichen Edelmetallverhältnisse und der Währungsfrage. Puttkammer \& Mühlenbrecht.

Spiethoff, A. (1955): Die wirtschaftlichen Wechsellagen, vol. 1. J.C.B. Mohr (Paul Siebeck).

SpreE, R. (1977): Die Wachstumszyklen der deutschen Wirtschaft von 1840 bis 1880. Duncker und Humblot.

(1978): Wachstumstrends und Konjunkturzyklen in der deutschen Wirtschaft von 1820 bis 1913. Vandenhoeck und Rupprecht.

Statistisches Reichsamt (1932): Das deutsche Volkseinkommen vor und nach dem Kriege. Einzelschriften zur Statistik des Deutschen Reichs, vol. 24. Hobbing.

Stern, F. R. (1977): Bismarck, Bleichroeder, and the Building of the German Empire. Knopf.

Stock, J. H., And M. W. (1989): "New Indexes of Coincident and Leading Economic Indicators," Macroeconomics Annual, 4.

Stock, J. H., And M. W. Watson (2005): "Implications of Dynamic Factor Models for VAR Analysis," mimeo.

Tooze, A. J. (2001): Statistics and the German state, 1900-1945, vol. 9 of Cambridge Studies in Modern Economic History. Cambridge University Press.

WAGENFÜHR, R. (1933): "Die Industriewirtschaft. Entwicklungstendenzen der deutschen und internationalen Industrieproduktion 1860 bis 1932," Vierteljahrshefte zur Konjunkturforschung, (Sonderheft 31). 
Wehler, H.-U. (1985): The German Empire, 1871-1918. Berg Publishers.

Woitek, U. (1998): "A Note on the Baxter King Filter," Discussion Paper, University of Glasgow.

ZuCKerindustrie, D. (1925): Denkschrift zum 75-jährigen Bestehen des Vereins der Deutschen Zucker-Industrie, 1850-1925. 


\section{Appendix}

\section{Data Sources Spree (1978)}

1820-1850:

- Sugar consumption in the years 1822-1849 was extrapolated with data from Festschrift of the German sugar industry (Zuckerindustrie 1925), and from Helling (1965) and the discount rate for 1820 and 1821 .

- The crop production series by Hoffmann (1965) is supplemented by potato and wheat production for Prussia, Saxony, Bavaria and Württemberg (Helling 1977).

- 1831-1834 yarn production comes from Dieterici (1931), 1820-30 is extrapolated using cotton imports and single data points from Kirchhain (1971).

- Scottish import prices 1830-1852 are supplemented with FOB-prices in Glasgow and 1820-1830 with prices for English iron in Hamburg.

- Iron production prior to 1834 is extrapolated using data from Prussia, Saxony and Nassau given in Marchand (1939). Alsace-Lorraine is included after 1871, prior to that the Zollverein is covered.

- Private discount rates are reported from Bremen for 1820-1824, from Hamburg for 1824-1870 and from Berlin 1870-1913.

1851-1913:

- The demographic series were originally assembled by Hoffmann (1965). Also net crop production and sugar consumption are provided here.

- Prussian coal mining and labor productivity in Dortmund are provided by Holtfrerich (1973).

- Kirchhain (1971) delivers most of the textile industry series, i.e. spinning profits, yarn production, and gross cotton investment.

- All wholesale prices can be found in Jacobs and Richter (1935).

- Marchand (1939) is the main source for pig iron production.

- The interest rates and bills of exchange series are assembled from many different sources. The main sources are Müssig $(1920)$ and Soetbeer $(1886,1855)$ for the private discount rate. Spree (1977) provides the core for the bills of exchange series supplemented by Spiethoff (1955).

- The bankruptcies series can be found in Gehrmann (1913). 

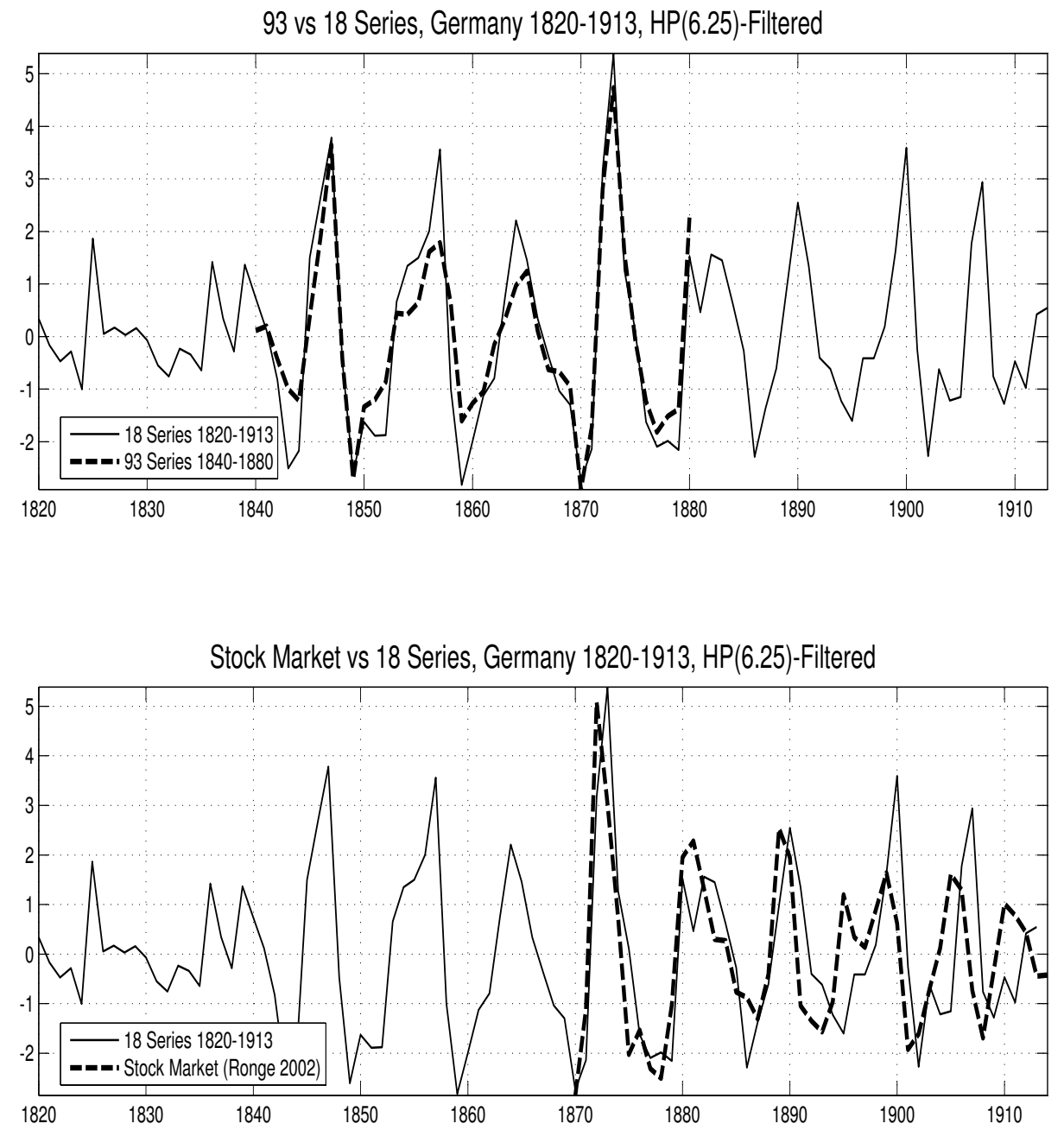

Figure 1: Factor from 18 time series vs 93 series (upper panel) and stock market (lower panel, Ronge 2002), Germany 1820-1913. 


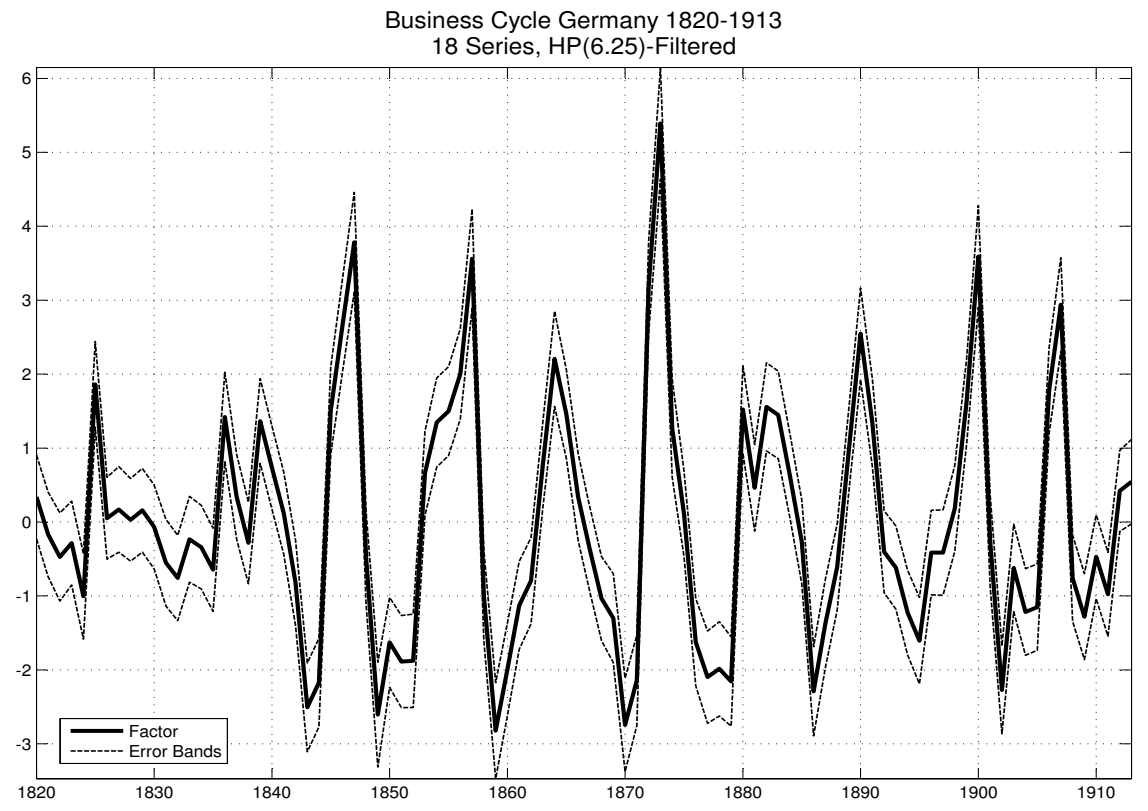

Figure 2: Factor from 18 time series, Germany 1820-1913. 
Agriculture vs 93 Series, Germany 1840-1880, HP(6.25)-Filtered

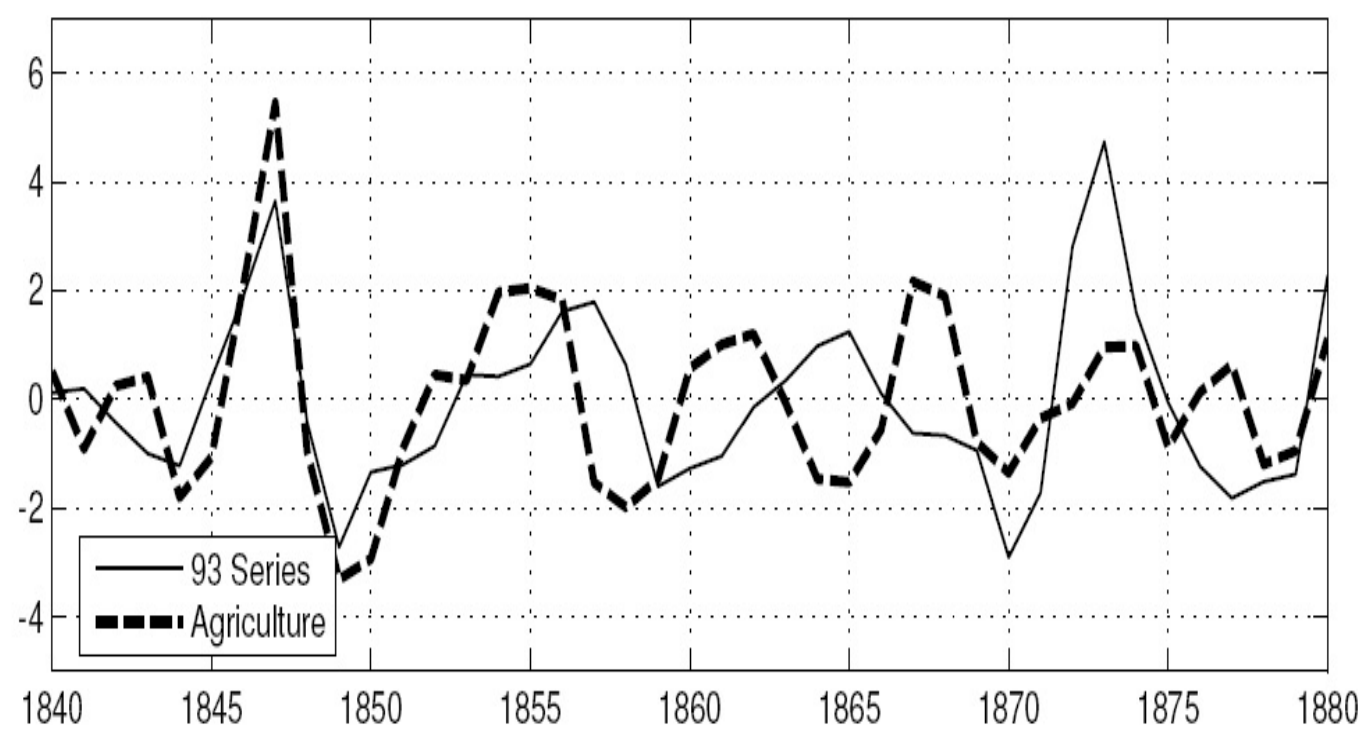

Construction vs 93 Series, Germany 1840-1880, HP(6.25)-Filtered

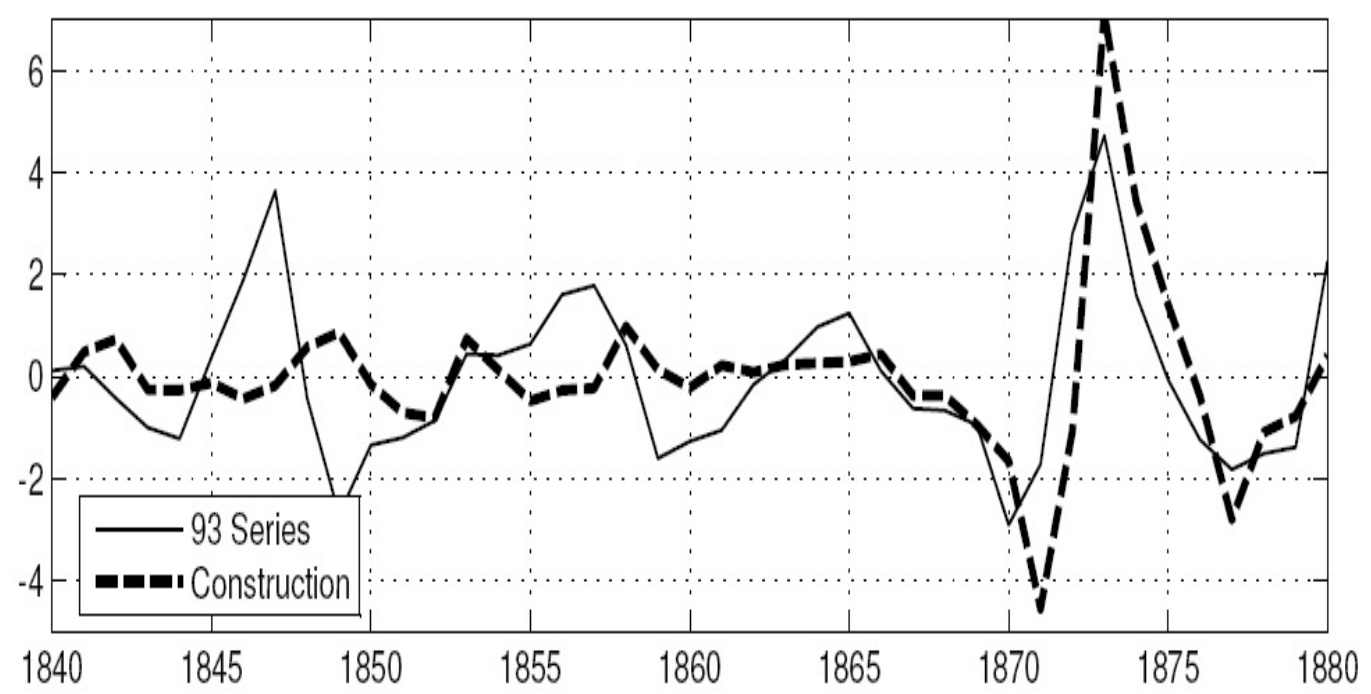

Figure 3: Factor from 93 time series vs subfactors for agriculture and construction, Germany 1840-1880. 
Heavy Industries vs 93 Series, Germany 1840-1880, HP(6.25)-Filtered

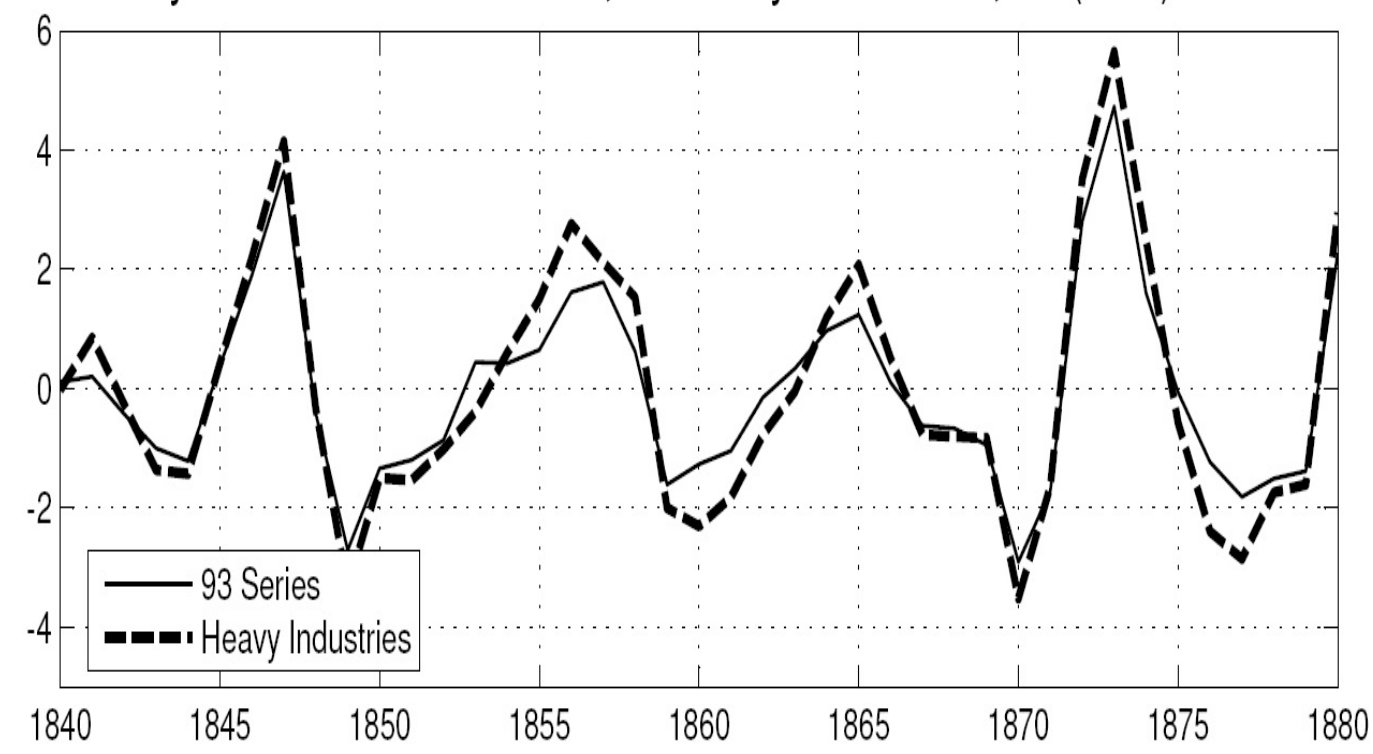

Textile Industry vs 93 Series, Germany 1840-1880, HP(6.25)-Filtered

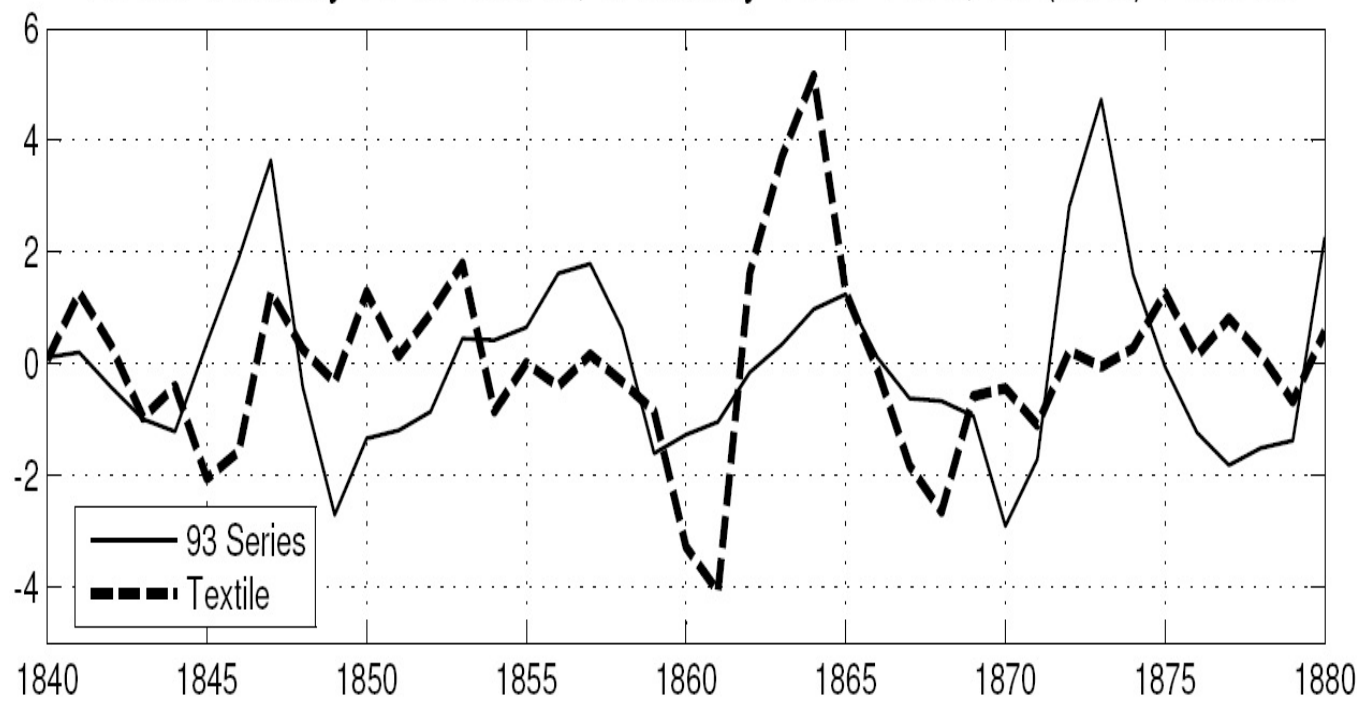

Figure 4: Factor from 93 time series vs subfactors for heavy industries and textile industry, Germany 1840-80. 
Factor Loadings Germany 1820-1913

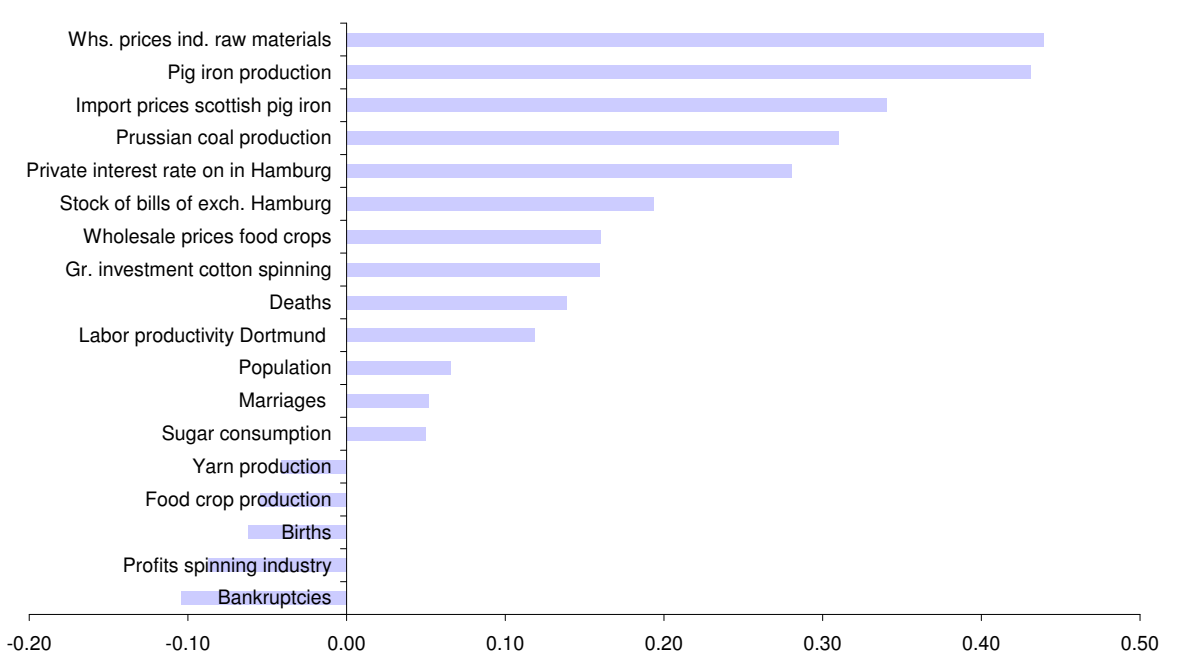

Figure 5: Factor loadings from 18 time series, Germany 1820-1913.

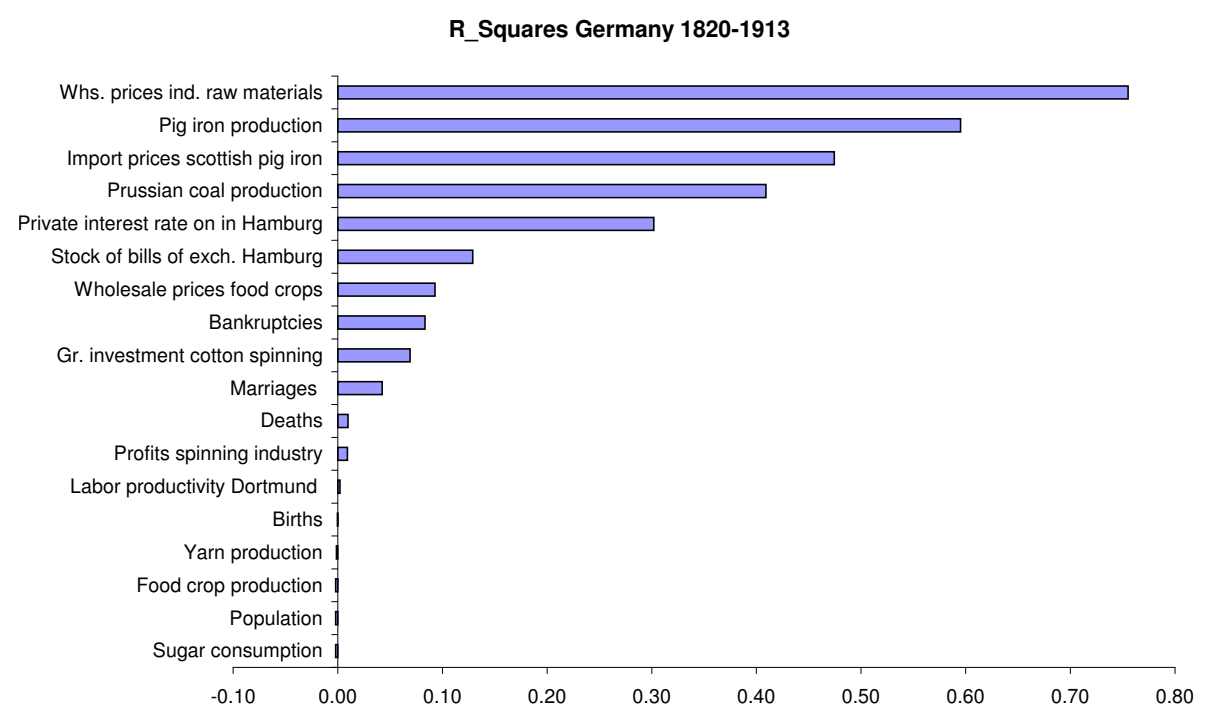

Figure 6: $R^{2}$ from 18 time series, Germany 1820-1913. 


\section{Factor Loadings Germany 1820-1850}

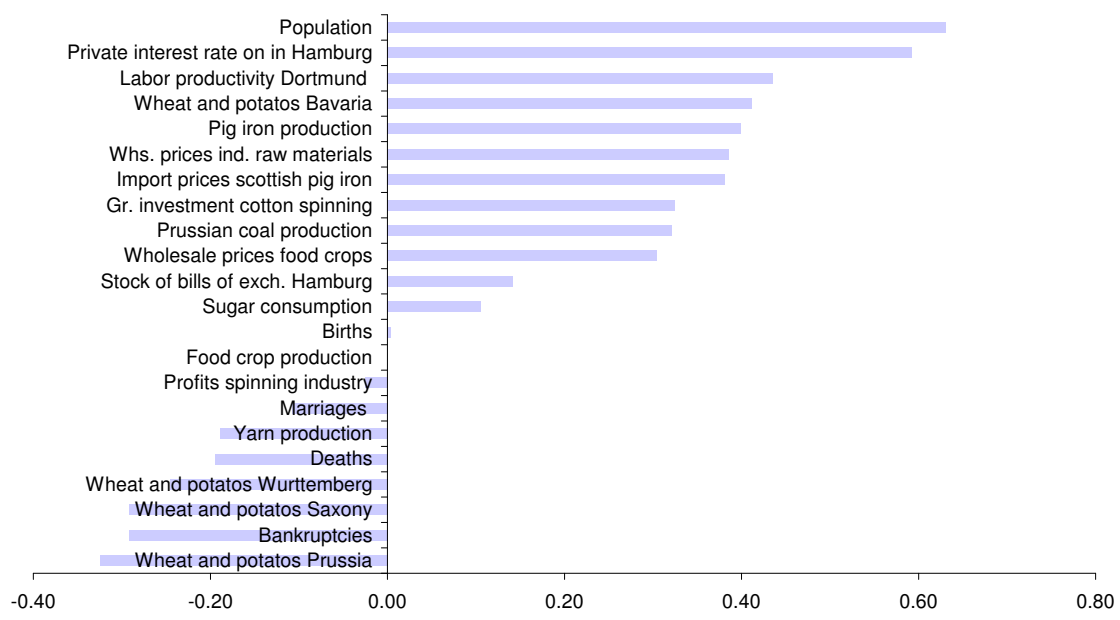

Figure 7: Factor loadings from 18 time series, Germany 1820-1850.

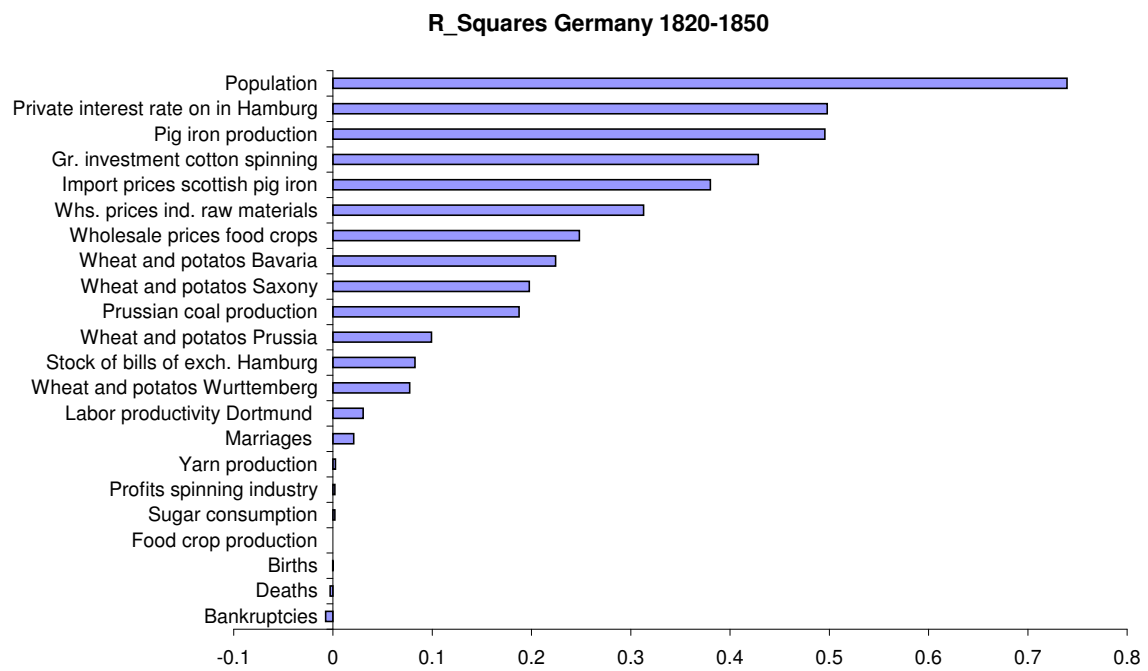

Figure 8: $R^{2}$ from 18 time series, Germany 1820-1850. 


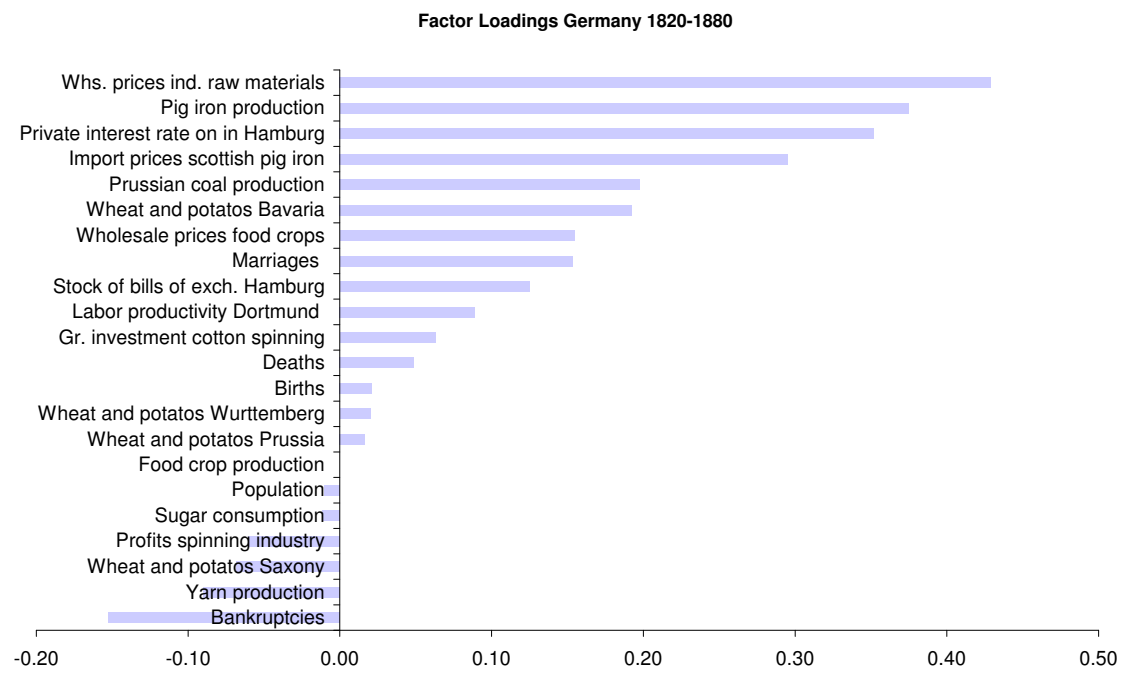

Figure 9: Factor loadings from 18 time series, Germany 1820-1880.

R_Squares Germany $1820-1880$

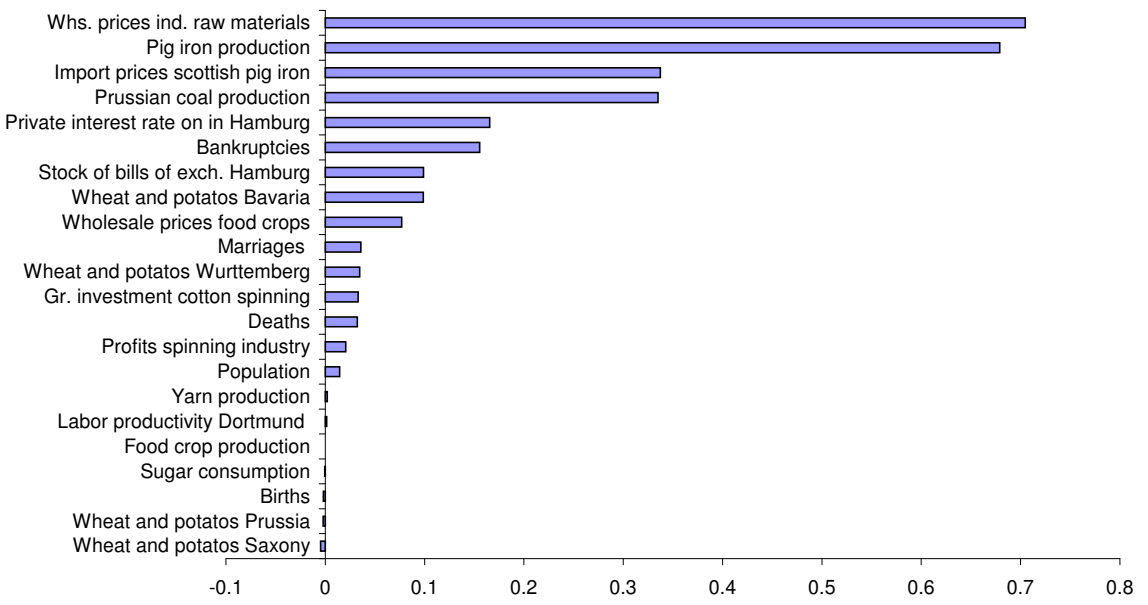

Figure 10: $R^{2}$ from 18 time series, Germany 1820-1880. 
Real NNP (Compromise) vs Factor (18 Series), Germany 1820-1913, HP(6.25)-Filtered

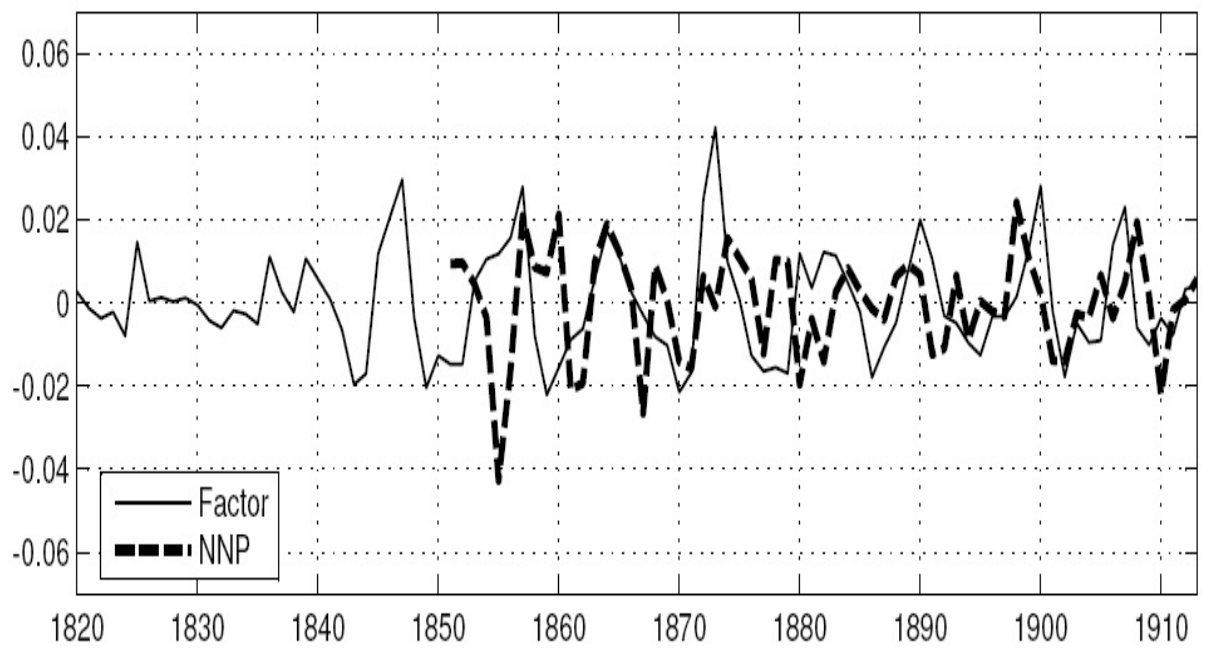

Real NNP (Output) vs Factor (18 Series), Germany 1820-1913, HP(6.25)-Filtered

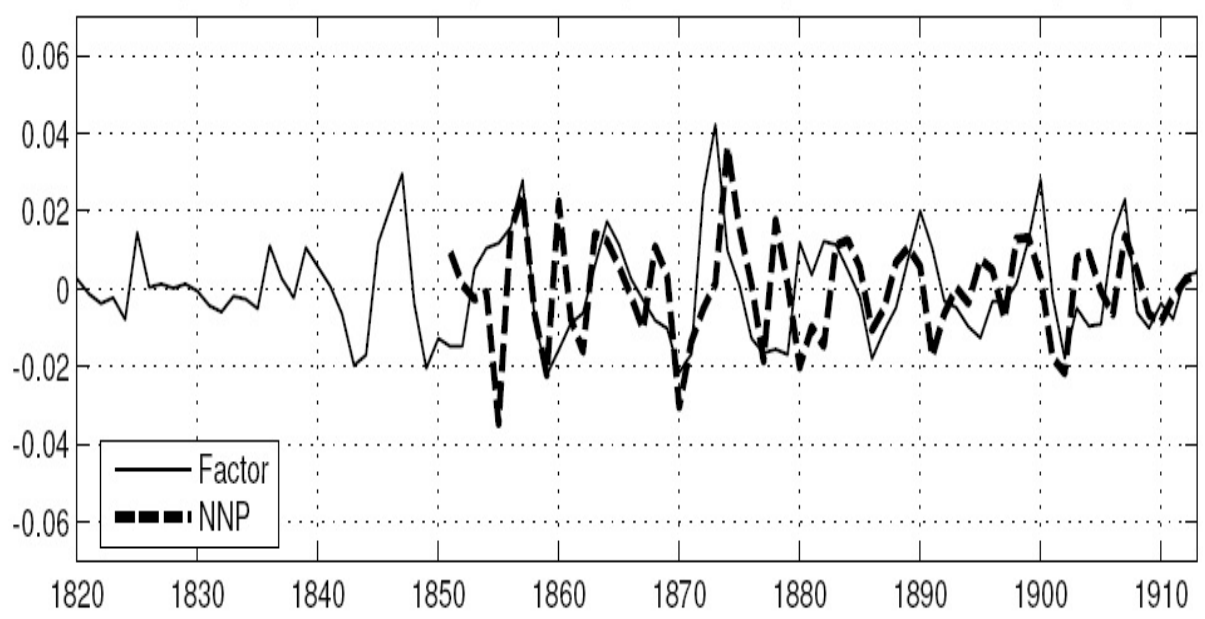

Figure 11: Factor from 18 time series vs Burhop and Wolff's (2005) "Compromise", and "Output" NNP-estimates. 
Real NNP (Expenditure) vs Factor (18 Series), Germany 1820-1913, HP(6.25)-Filtered

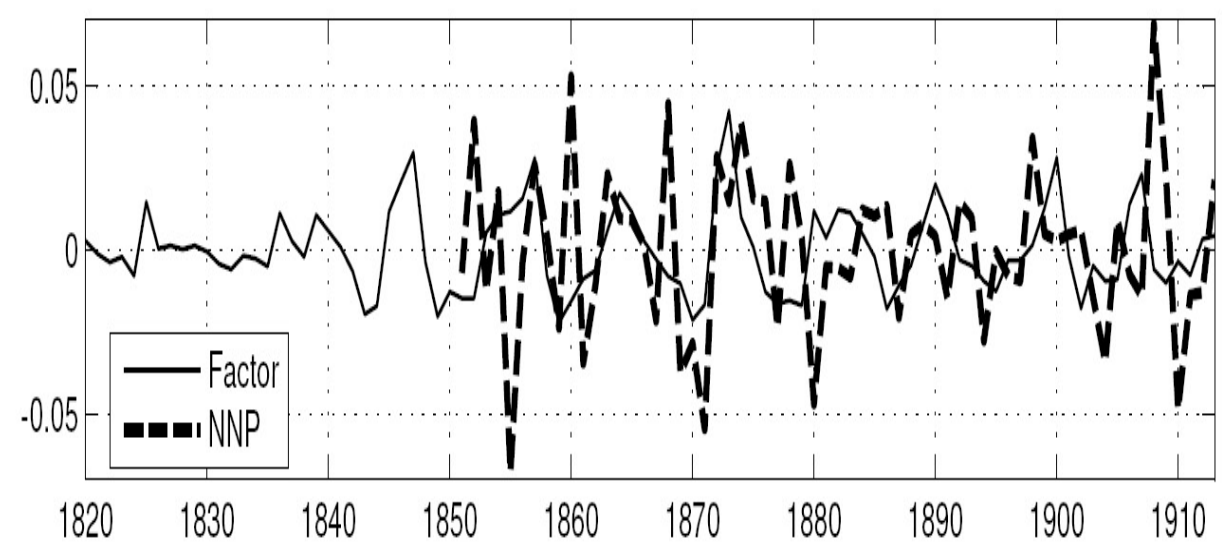

Real NNP (Income) vs Factor (18 Series), Germany 1820-1913, HP(6.25) -Filtered

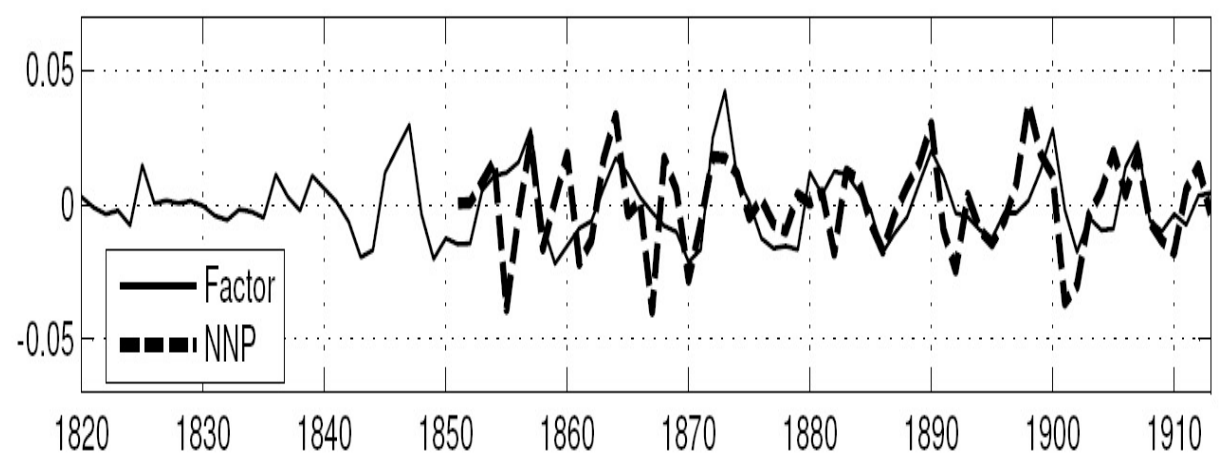

Real NNP (Taxes) vs Factor (18 Series), Germany 1820-1913, HP(6.25) -Filtered

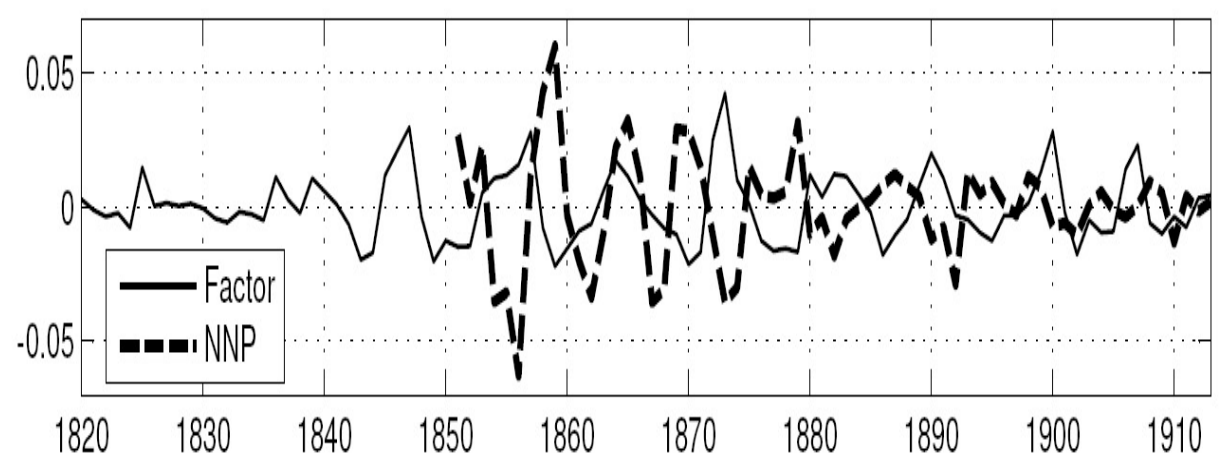

Figure 12: Factor from 18 time series vs Burhop and Wolff's (2005) "Expenditure", "Income", and "Taxes" NNP-estimates. 


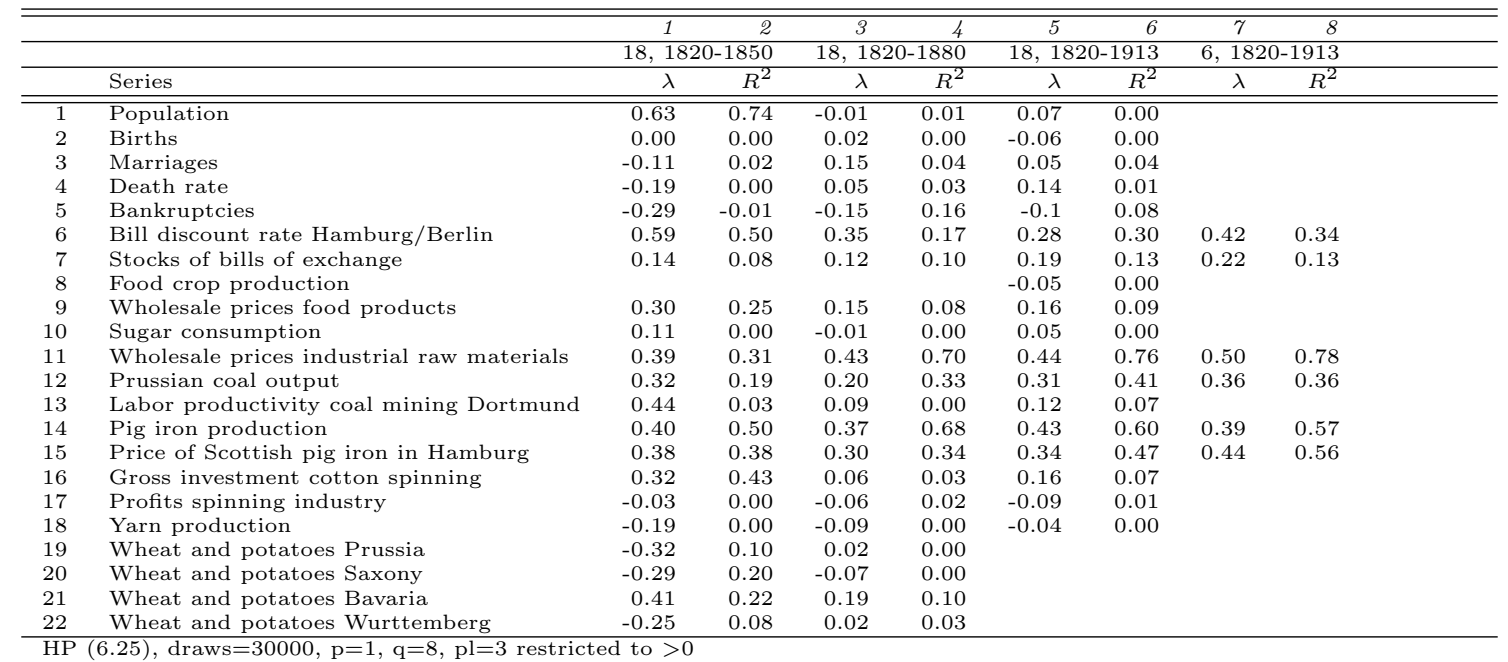

Table 1: Factor loadings $(\lambda)$ and $R^{2} \mathrm{~s}$

\begin{tabular}{ccccccccc}
\hline \hline & Factor from 18 Series & \multicolumn{2}{c}{ Burns/Mitchell (1946) } & \multicolumn{2}{c}{ Spiethoff (1955) } & \multicolumn{2}{c}{ Burhop\&Wolff (2005) } \\
\hline & Trough & Peak & Trough & Peak & Trough & Peak & Trough & Peak \\
\hline \hline 1 & - & 1825 & - & - & - & - & - & - \\
2 & - & 1836 & - & - & - & - & - & - \\
3 & 1843 & 1847 & - & - & - & - & - & - \\
4 & 1851 & 1857 & - & - & - & - & 1855 & 1859 \\
5 & 1859 & 1864 & 1866 & - & - & - & 1862 & 1864 \\
6 & 1870 & 1873 & 1870 & 1872 & - & $1872-73$ & 1877 & 1869 \\
7 & 1879 & 1882 & 1878 & 1882 & $1878-79$ & $1881-82$ & 1880 & 1879 \\
8 & 1886 & 1890 & 1886 & 1890 & $1883-84$ & $1889-90$ & 1892 & 1888 \\
9 & 1895 & 1900 & 1894 & 1900 & $1893-94$ & $1899-00$ & 1896 & 1898 \\
10 & 1902 & - & 1902 & 1903 & $1901-02$ & - & 1902 & 1905 \\
11 & - & 1907 & 1904 & 1907 & - & $1906-07$ & - & - \\
12 & 1911 & - & 1908 & 1913 & $1908-09$ & $1912-13$ & 1910 & 1908 \\
\hline
\end{tabular}

Spiethoff's dating procedure adapted for comparison: Peaks between slumps and booms, troughs between booms and slumps.

Compromise from Burhop and Wolff (2005). They also report troughs in 1873, 1877,

$1886 / 87,1906$, and peaks in $1874,1878,1883 / 84,1893$, and 1905 , but with lower intensity.

Table 2: Comparison of business cycle dating for Germany, 1820-1913. 


\begin{tabular}{|c|c|c|c|c|c|c|c|c|}
\hline & & & & 1 & 2 & 3 & 4 & 5 \\
\hline & Series & Units & & 6 & 18 & 93 & Ind. & Const. \\
\hline 1 & population & 1000 & $\mathrm{rnb}$ & & $\mathrm{x}$ & $\mathrm{x}$ & & \\
\hline 2 & price index of ind. raw materials & $1913=1$ & & $\mathrm{x}$ & $\mathrm{x}$ & $\mathrm{x}$ & & \\
\hline 3 & wholesale price index & $1913=1$ & & & & $\mathrm{x}$ & & \\
\hline 4 & corporate bankruptcies & $\mathrm{nr}$ & $\mathrm{rnb}$ & & $\mathrm{x}$ & $\mathrm{x}$ & & \\
\hline 5 & corporate bankruptcies in Prussia & $\mathrm{nr}$ & & & & $\mathrm{x}$ & & \\
\hline 6 & corporate bankruptcies in Saxony & $\mathrm{nr}$ & & & & $\mathrm{x}$ & & \\
\hline 7 & $\mathrm{nr}$ of workers Pruss. mining ind. & $\mathrm{nr}$ & & & & & & \\
\hline 8 & prod. Pruss. mining ind. & $1000 \mathrm{t}$ & & & & & & \\
\hline 9 & value of prod. Pruss. mining ind. & $1000 \mathrm{M}$ & & & & & & \\
\hline 10 & wage index German mining ind. & $1900=1$ & & & & & & \\
\hline 11 & $\mathrm{nr}$ of workers mining ind. & $\mathrm{nr}$ & $\mathrm{Z} / \mathrm{G}$ & & & & & \\
\hline 12 & coal prod. & $1000 \mathrm{t}$ & $\mathrm{Z} / \mathrm{G}$ & & & & & \\
\hline 13 & value of coal prod. & $1000 \mathrm{M}$ & $\mathrm{Z} / \mathrm{G}$ & & & & & \\
\hline 14 & price index for coal & $1913=1$ & $\mathrm{Z} / \mathrm{G}$ & & & & & \\
\hline 15 & price for English coal in Hamburg & $\mathrm{M} / \mathrm{t}$ & & & & $\mathrm{x}$ & $\mathrm{x}$ & \\
\hline 16 & $\mathrm{nr}$ of workers coal mining ind. & $\mathrm{nr}$ & & & & & & \\
\hline 17 & coal prod. Pruss. mining ind. & $\mathrm{mt}$ & & $\mathrm{x}$ & $\mathrm{x}$ & $\mathrm{x}$ & $\mathrm{x}$ & \\
\hline 18 & value of coal prod. Pruss. mining ind. & $1000 \mathrm{M}$ & & & & & & \\
\hline 19 & total ann. wages Pruss. coal mining ind. & $\mathrm{mM}$ & & & & & & \\
\hline 20 & total ann. wages Ruhr valley coal mining ind. & $\mathrm{mM}$ & & & & & & \\
\hline 21 & avg. ann. wages, Pruss. coal mining ind. & M/cap & & & & $\mathrm{x}$ & $\mathrm{x}$ & \\
\hline 22 & ann. wages Upper Silesia & $\mathrm{M} /$ cap & & & & $\mathrm{x}$ & $\mathrm{x}$ & \\
\hline 23 & ann. wages Ruhr valley & & & & & $\mathrm{x}$ & $\mathrm{x}$ & \\
\hline 24 & ann. wages Saarland & M/cap & & & & $\mathrm{x}$ & $\mathrm{x}$ & \\
\hline 25 & avg. price of Pruss. coal ex mine & $\mathrm{M} / \mathrm{t}$ & & & & $\mathrm{x}$ & $\mathrm{x}$ & \\
\hline 26 & avg. price of Lower Silesian coal ex mine & $\mathrm{M} / \mathrm{t}$ & & & & $\mathrm{x}$ & $\mathrm{x}$ & \\
\hline 27 & avg. price of Upper Silesian coal ex mine & $\mathrm{M} / \mathrm{t}$ & & & & $\mathrm{x}$ & $\mathrm{x}$ & \\
\hline 28 & avg. price of Ruhr valley coal ex mine & $\mathrm{M} / \mathrm{t}$ & & & & $\mathrm{x}$ & $\mathrm{x}$ & \\
\hline 29 & avg. price of Saarland coal ex mine & $\mathrm{M} / \mathrm{t}$ & & & & $\mathrm{x}$ & $\mathrm{x}$ & \\
\hline 30 & gross revenues, Ruhr valley coal mining ind. & $\mathrm{mM}$ & & & & & & \\
\hline 31 & indicator of capital income, Pruss. coal mining & $1000 \mathrm{M}$ & & & & $\mathrm{x}$ & $\mathrm{x}$ & \\
\hline 32 & ratio capital/labor income Pruss. coal mining & & & & & & & \\
\hline 33 & shared profits Ruhr valley coal prod. & $\mathrm{M} / \mathrm{t}$ & & & & & & \\
\hline 34 & capital return per ton Pruss. coal mining & $\mathrm{M} / \mathrm{t}$ & & & & & & \\
\hline 35 & nrs of workers Saxonian coal mining & & & & & $\mathrm{x}$ & $\mathrm{x}$ & \\
\hline 36 & coal prod. Saxony & $1000 \mathrm{t}$ & & & & $\mathrm{x}$ & $\mathrm{x}$ & \\
\hline 37 & total ann. wages Saxonian coal mining ind. & $\mathrm{mM}$ & & & & & & \\
\hline 38 & avg. ann. wages Saxonian coal mining ind. & M/cap & & & & $\mathrm{x}$ & $\mathrm{x}$ & \\
\hline 39 & index of gross value added German transport ind. & $1880=1$ & & & & & & \\
\hline 40 & index of transport volume inland navigation ind. & $1840=1$ & & & & $\mathrm{x}$ & & \\
\hline 41 & nr times distance of persons carried by railway & $\mathrm{mkm}$ & $\mathrm{G}$ & & & & & \\
\hline 42 & $\mathrm{nr}$ of tons times distance of freight transported & $\mathrm{mkm}$ & G & & & & & \\
\hline 43 & revenue from person carriage German railways & $\mathrm{mM}$ & & & & $\mathrm{x}$ & & \\
\hline 44 & revenue from freight transport German railways & $\mathrm{mM}$ & & & & $\mathrm{x}$ & & \\
\hline 45 & avg. capital return German railways & $\%$ & & & & & & \\
\hline 46 & $\mathrm{nr}$ times distance of persons carried by railway & $\mathrm{mkm}$ & $\mathrm{P}$ & & & & & \\
\hline 47 & $\mathrm{nr}$ of tons times distance of freight transported & $\mathrm{mkm}$ & $\mathrm{P}$ & & & & & \\
\hline 48 & revenue from person carriage Pruss. railways & $\mathrm{mM}$ & & & & $\mathrm{x}$ & & \\
\hline 49 & revenue from freight transport Pruss. railways & $\mathrm{mM}$ & & & & $\mathrm{x}$ & & \\
\hline 50 & index of construction activity & $1913=1$ & & & & $\mathrm{x}$ & & $\mathrm{x}$ \\
\hline 51 & wage index German construction ind. & $1900=1$ & & & & $\mathrm{x}$ & & $\mathrm{x}$ \\
\hline 52 & price index building materials constant weights & $1913=1$ & & & & $\mathrm{x}$ & & $\mathrm{x}$ \\
\hline 53 & whs. price index building materials variable weights & $1913=1$ & & & & & & \\
\hline 54 & whs. price index for lime & $1913=1$ & & & & $\mathrm{x}$ & & $\mathrm{x}$ \\
\hline 55 & avg. price of lumber & M & & & & $\mathrm{x}$ & & $\mathrm{x}$ \\
\hline 56 & $\mathrm{nr}$ of workers metallurgical ind. & $\mathrm{nr}$ & & & & & & \\
\hline 57 & prod. volume Pruss. metallurgical ind. & $1000 \mathrm{t}$ & & & & & & \\
\hline 58 & prod. value Pruss. metallurgical ind. & $1000 \mathrm{M}$ & & & & & & \\
\hline 59 & nr of workers Pruss. iron ind. & $\mathrm{nr}$ & & & & $\mathrm{x}$ & $\mathrm{x}$ & \\
\hline 60 & prod. volume Pruss. iron ind. & $1000 \mathrm{t}$ & & & & $\mathrm{x}$ & $\mathrm{x}$ & \\
\hline 61 & prod. value Pruss. iron ind. & $1000 \mathrm{M}$ & & & & & $\mathrm{x}$ & \\
\hline 62 & $\mathrm{nr}$ of workers pig iron ind. & $\mathrm{nr}$ & $\mathrm{Z} / \mathrm{G}$ & & & $\mathrm{x}$ & $\mathrm{x}$ & \\
\hline 63 & consumption of bar iron incl. rails & $1000 \mathrm{t}$ & $\mathrm{Z} / \mathrm{G}$ & & & $\mathrm{x}$ & $\mathrm{x}$ & \\
\hline 64 & index of steel prod. & $1913=1$ & & & & $\mathrm{x}$ & $\mathrm{x}$ & \\
\hline 65 & $\mathrm{nr}$ of workers non-iron metallurgical ind. & & $\mathrm{Z} / \mathrm{G}$ & & & $\mathrm{x}$ & $\mathrm{x}$ & \\
\hline 66 & prod. volume non-iron metallurgical ind. & $1000 \mathrm{t}$ & $\mathrm{Z} / \mathrm{G}$ & & & $\mathrm{x}$ & $\mathrm{x}$ & \\
\hline 67 & prod. value non-iron metallurgical ind. & $1000 \mathrm{M}$ & $\mathrm{Z} / \mathrm{G}$ & & & & & \\
\hline 68 & lead prod. & $1000 \mathrm{t}$ & $\mathrm{Z} / \mathrm{G}$ & & & $\mathrm{x}$ & $\mathrm{x}$ & \\
\hline 69 & copper prod. & $1000 \mathrm{t}$ & $\mathrm{Z} / \mathrm{G}$ & & & $\mathrm{x}$ & $\mathrm{x}$ & \\
\hline 70 & $\mathrm{nr}$ of worker non-iron metallurgical ind. & $\mathrm{nr}$ & $\mathrm{P}$ & & & & & \\
\hline 71 & prod. volume non-iron metallurgical ind. & $1000 t$ & $\mathrm{P}$ & & & & & \\
\hline 72 & prod. value non-iron metallurgical ind. & $1000 \mathrm{M}$ & $\mathrm{P}$ & & & & & \\
\hline 73 & pig iron prod. volume & $1000 \mathrm{t}$ & $\mathrm{Z} / \mathrm{G}$ & $\mathrm{x}$ & $\mathrm{x}$ & $\mathrm{x}$ & $\mathrm{x}$ & \\
\hline 74 & pig iron prod. value & $1000 \mathrm{M}$ & $\mathrm{Z} / \mathrm{G}$ & & & & & \\
\hline 75 & avg. price metallurgical products ex works & $\mathrm{M} / \mathrm{t}$ & & & & $\mathrm{x}$ & $\mathrm{x}$ & \\
\hline 76 & price index of iron & $1870=1$ & & & & & & \\
\hline 77 & price index of non-iron metals constant weights & $1913=1$ & $\mathrm{Z} / \mathrm{G}$ & & & & & \\
\hline 78 & price index of non-iron metals variable weights & $1913=1$ & $\mathrm{Z} / \mathrm{G}$ & & & & & \\
\hline 79 & avg. price of copper ex works & $\mathrm{M} / \mathrm{kg}$ & & & & $\mathrm{x}$ & $\mathrm{x}$ & \\
\hline 80 & price of zinc Upper Silesia ex works & $\mathrm{M} / z \mathrm{t}$. & & & & $\mathrm{x}$ & $\mathrm{x}$ & \\
\hline 81 & avg. price of pig iron ex works & $\mathrm{M} / \mathrm{t}$ & $\mathrm{Z} / \mathrm{G}$ & & & $\mathrm{x}$ & $\mathrm{x}$ & \\
\hline 82 & price of Scottish pig iron ex Hamburg & $\mathrm{M} / \mathrm{t}$ & & $\mathrm{x}$ & $\mathrm{x}$ & $\mathrm{x}$ & $\mathrm{x}$ & \\
\hline 83 & index of machine building & $1880=1$ & & & & $\mathrm{x}$ & & \\
\hline 84 & price index of ind. equipment and inventories & $1913=1$ & & & & $\mathrm{x}$ & & \\
\hline 85 & price index of agricultural machines & $1913=1$ & & & & $\mathrm{x}$ & & \\
\hline 86 & price index of steam engines & $1913=1$ & & & & $\mathrm{x}$ & & \\
\hline 87 & price index of investment goods & $1913=1$ & & & & $\mathrm{x}$ & & \\
\hline 88 & prod. index of textile ind. & $1840=1$ & & & & & & \\
\hline
\end{tabular}

Units: $\mathrm{M}=$ Mark, $\mathrm{nr}=$ number, $\mathrm{pf}=$ pfennig $=1 / 100$ Mark, $\mathrm{t}=1000 \mathrm{~kg}$

Units: zt. $=50 \mathrm{~kg}, \mathrm{~m}=$ million, cap. = capita

$18=18$ series $1820-1913,93=93$ series $1840-1880$, Ind. $=31$ series heavy industrie

Const. $=5$ series construction, Tex. $=29$ series textile industry, Agr. $=22$ series agriculture 


\begin{tabular}{|c|c|c|c|c|c|c|c|c|c|c|}
\hline & & & & 1 & 2 & 3 & 4 & 5 & 6 & 7 \\
\hline & Series & Units & & 6 & 18 & 93 & Ind. & Cnst. & Tex. & Agr. \\
\hline 89 & price index of textiles constant weights & $1913=1$ & & & & & & & $\mathrm{x}$ & \\
\hline 90 & price index of textiles variable weights & $1913=1$ & & & & & & & & \\
\hline 91 & exp. volume raw cotton & $1000 \mathrm{t}$ & $\mathrm{Z} / \mathrm{G}$ & & & $\mathrm{x}$ & & & $\mathrm{x}$ & $\mathrm{x}$ \\
\hline 92 & imp. volume raw cotton & $1000 \mathrm{t}$ & $\mathrm{Z} / \mathrm{G}$ & & & $\mathrm{x}$ & & & $\mathrm{x}$ & $\mathrm{x}$ \\
\hline 93 & price of cotton ex Bremen/Hamburg & $\mathrm{M} / \mathrm{kg}$ & & & & $\mathrm{x}$ & & & $\mathrm{x}$ & $\mathrm{x}$ \\
\hline 94 & prod. of yarn & $1000 \mathrm{t}$ & & & $\mathrm{x}$ & $\mathrm{x}$ & & & $\mathrm{x}$ & \\
\hline 95 & stock of cotton spindles & units & & & & & & & $\mathrm{x}$ & \\
\hline 96 & avg. ann. wages spinning ind. & M/cap & & & & $\mathrm{x}$ & & & $\mathrm{x}$ & \\
\hline 97 & exp. volume yarn & $1000 z$ t. & $\mathrm{Z} / \mathrm{G}$ & & & & & & $\mathrm{x}$ & \\
\hline 98 & imp. volume yarn & 1000zt. & $\mathrm{Z} / \mathrm{G}$ & & & & & & $\mathrm{x}$ & \\
\hline 99 & avg. price of yarn & $\mathrm{M} / \mathrm{kg}$ & & & & $\mathrm{x}$ & & & $\mathrm{x}$ & \\
\hline 100 & unit profits spinning ind. & $\mathrm{M} / \mathrm{kg}$ & & & $\mathrm{x}$ & $\mathrm{x}$ & & & $\mathrm{x}$ & \\
\hline 101 & prod. cotton weaving & $1000 \mathrm{t}$ & & & & $\mathrm{x}$ & & & $\mathrm{x}$ & \\
\hline 102 & exp. volume cotton products & 1000zt. & & & & $\mathrm{x}$ & & & $\mathrm{x}$ & \\
\hline 103 & imp. volume cotton products & 1000zt. & $\mathrm{Z} / \mathrm{G}$ & & & $\mathrm{x}$ & & & $\mathrm{x}$ & \\
\hline 104 & unit profits weaving ind. & $\mathrm{M} / \mathrm{kg}$ & & & & & & & $\mathrm{x}$ & \\
\hline 105 & avg. price cotton textile & $\mathrm{M} / \mathrm{kg}$ & & & & $\mathrm{x}$ & & & $\mathrm{x}$ & \\
\hline 106 & price index for linen & $1913=1$ & & & & $\mathrm{x}$ & & & $\mathrm{x}$ & \\
\hline 107 & exp. volume wool & 1000zt. & & & & $\mathrm{x}$ & & & $\mathrm{x}$ & $\mathrm{x}$ \\
\hline 108 & imp. volume wool & 1000zt. & $\mathrm{Z} / \mathrm{G}$ & & & $\mathrm{x}$ & & & $\mathrm{x}$ & $\mathrm{x}$ \\
\hline 109 & price index for wool & $1913=1$ & & & & $\mathrm{x}$ & & & $\mathrm{x}$ & $\mathrm{x}$ \\
\hline 110 & prod. index of woollen yarn & $1913=1$ & & & & & & & $\mathrm{x}$ & \\
\hline 111 & prod. index of woollen textiles & $1913=1$ & & & & & & & & \\
\hline 112 & consumption of woollen textiles & $1000 \mathrm{t}$ & $\mathrm{Z} / \mathrm{G}$ & & & $\mathrm{x}$ & & & $\mathrm{x}$ & \\
\hline 113 & exp. volume woollen textiles & 1000zt. & & & & & & & $\mathrm{x}$ & \\
\hline 114 & imp. volume woollen textiles & 1000zt. & $\mathrm{Z} / \mathrm{G}$ & & & & & & $\mathrm{x}$ & \\
\hline 115 & prod. index of silk & $1913=1$ & & & & $\mathrm{x}$ & & & $\mathrm{x}$ & \\
\hline 116 & prod. silk products & $1000 \mathrm{t}$ & & & & & & & $\mathrm{x}$ & \\
\hline 117 & price index of raw silk & $1913=1$ & & & & $\mathrm{x}$ & & & $\mathrm{x}$ & \\
\hline 118 & indicator of note circulation year end & $\mathrm{mM}$ & & & & & & & & \\
\hline 119 & total deposits retail banks year end & $\mathrm{mM}$ & & & & $\mathrm{x}$ & & & & \\
\hline 120 & total deposits commercial banks year end & $\mathrm{mM}$ & & & & & & & & \\
\hline 121 & lombard loans of retail and credit banks year end & $\mathrm{mM}$ & & & & $\mathrm{x}$ & & & & \\
\hline 122 & total value of bills of exchange retail banks year end & $\mathrm{mM}$ & & $\mathrm{x}$ & $\mathrm{x}$ & $\mathrm{x}$ & & & & \\
\hline 123 & avg. price of bonds German stock markets & $\%$ & & & & & & & & \\
\hline 124 & avg. effective return on Pruss. government bonds & $\%$ & & & & & & & & \\
\hline 125 & avg. bank discount rate Hamb./Berl. & $\%$ & & $\mathrm{x}$ & $\mathrm{x}$ & $\mathrm{x}$ & & & & \\
\hline 126 & ann. high of bank discount rate Prussia & $\%$ & & & & & & & & \\
\hline 127 & ann. low of bank discount rate Prussia & $\%$ & & & & & & & & \\
\hline 128 & ann. high of private disc. rate Berlin stock market & $\%$ & & & & & & & & \\
\hline 129 & ann. low of private disc. rate Berlin stock market & $\%$ & & & & & & & & \\
\hline 130 & avg. private discount rate Hamburg stock market & $\%$ & & & & $\mathrm{x}$ & & & & \\
\hline 131 & ann. high of discount rate Hamburg stock market & $\%$ & & & & & & & & \\
\hline 132 & ann. low of private disc. rate Hamburg stock market & $\%$ & & & & & & & & \\
\hline 133 & prod. index food, beverage and tobacco ind. & $1913=1$ & & & & & & & & $\mathrm{x}$ \\
\hline 134 & avg. prices of imp.ed coffee ex Hamburg & $\mathrm{M} / 1 \mathrm{~kg}$ & & & & & & & & \\
\hline 135 & prod. volume sugar ind. & $1000 \mathrm{t}$ & & & & & & & & $\mathrm{x}$ \\
\hline 136 & price of sugar in Berlin & $\mathrm{M} / 1 \mathrm{~kg}$ & & & & & & & & \\
\hline 137 & avg. price of sugar in Hamburg & $\mathrm{M} / 1 \mathrm{~kg}$ & & & & & & & & \\
\hline 138 & value of net agricultural prod. 1913 prices & $\mathrm{mM}$ & & & $\mathrm{x}$ & $\mathrm{x}$ & & & & $\mathrm{x}$ \\
\hline 139 & value of net agricultural prod. current prices & $\mathrm{mM}$ & & & & & & & & \\
\hline 140 & prod. price index agricultural products & $1913=1$ & & & $\mathrm{x}$ & $\mathrm{x}$ & & & & $\mathrm{x}$ \\
\hline 141 & price index of rye in Berlin & $1913=1$ & & & & $\mathrm{x}$ & & & & $\mathrm{x}$ \\
\hline 142 & exp. price of rye in Hamburg & $\mathrm{M} / \mathrm{t}$ & & & & $\mathrm{x}$ & & & & $\mathrm{x}$ \\
\hline 143 & price index of wheat in Berlin & $1913=1$ & & & & & & & & $\mathrm{x}$ \\
\hline 144 & exp. price of wheat in Hamburg & $\mathrm{M} / \mathrm{t}$ & & & & & & & & $\mathrm{x}$ \\
\hline 145 & exp. of rye & $1000 \mathrm{t}$ & $\mathrm{Z} / \mathrm{G}$ & & & $\mathrm{x}$ & & & & $\mathrm{x}$ \\
\hline 146 & imp. of rye & $1000 \mathrm{t}$ & $\mathrm{Z} / \mathrm{G}$ & & & $\mathrm{x}$ & & & & $\mathrm{x}$ \\
\hline 147 & exp. of wheat & $1000 \mathrm{t}$ & $\mathrm{Z} / \mathrm{G}$ & & & & & & & $\mathrm{x}$ \\
\hline 148 & imp. of wheat & $1000 \mathrm{t}$ & $\mathrm{Z} / \mathrm{G}$ & & & & & & & $\mathrm{x}$ \\
\hline 149 & exp. value of Europ. foodstuffs const. prices & $\mathrm{mM}$ & $\mathrm{Z} / \mathrm{G}$ & & & $\mathrm{x}$ & & & & $\mathrm{x}$ \\
\hline 150 & imp. value of Europ. foodstuffs const. prices & $\mathrm{mM}$ & $\mathrm{Z} / \mathrm{G}$ & & & & & & & $\mathrm{x}$ \\
\hline 151 & exp. value of raw materials const. prices & $\mathrm{mM}$ & $\mathrm{Z} / \mathrm{G}$ & & & $\mathrm{x}$ & & & & \\
\hline 152 & exp. value of intermediate products const. prices & $\mathrm{mM}$ & $\mathrm{Z} / \mathrm{G}$ & & & & & & & \\
\hline 153 & exp. value finished products const. prices & $\mathrm{mM}$ & $\mathrm{Z} / \mathrm{G}$ & & & $\mathrm{x}$ & & & & \\
\hline 154 & total exp. value const. prices & $\mathrm{mM}$ & $\mathrm{Z} / \mathrm{G}$ & & & $\mathrm{x}$ & & & & \\
\hline 155 & imp. value Europ. foodstuffs const. prices & $\mathrm{mM}$ & $\mathrm{Z} / \mathrm{G}$ & & & $\mathrm{x}$ & & & & \\
\hline 156 & imp. value colonial foodstuffs const. prices & $\mathrm{mM}$ & $\mathrm{Z} / \mathrm{G}$ & & & & & & & \\
\hline 157 & imp. value of raw materials const. prices & $\mathrm{mM}$ & $\mathrm{Z} / \mathrm{G}$ & & & $\mathrm{x}$ & & & & \\
\hline 158 & exp. value colonial foodstuffs const. prices & $\mathrm{mM}$ & $\mathrm{Z} / \mathrm{G}$ & & & & & & & \\
\hline 159 & per capita consumption of cotton products & & & & & & & & & \\
\hline 160 & per capita consumption of woollen products & & & & & & & & & \\
\hline 161 & per capita consumption of silk products & & & & & & & & & \\
\hline 162 & sugar exp.s & & & & & & & & & \\
\hline 163 & sugar consumption & $1000 \mathrm{t}$ & & & $\mathrm{x}$ & $\mathrm{x}$ & & & & $\mathrm{x}$ \\
\hline 164 & labor productivity coal mining Dortmund & $\mathrm{t} / \mathrm{cap}$ & & & $\mathrm{x}$ & $\mathrm{x}$ & & & & \\
\hline 165 & gross investment cotton spinning works & & & & $\mathrm{x}$ & $\mathrm{x}$ & & & $\mathrm{x}$ & \\
\hline 166 & marriages & $\mathrm{nr} / 10^{5}$ & & & $\mathrm{x}$ & $\mathrm{x}$ & & & & \\
\hline 167 & birth rate & $\mathrm{nr} / 10^{5}$ & & & $\mathrm{x}$ & $\mathrm{x}$ & & & & \\
\hline 168 & death rate & $\mathrm{nr} / 10^{5}$ & & & $\mathrm{x}$ & $\mathrm{x}$ & & & & \\
\hline
\end{tabular}

Units: $\mathrm{zt}=50 \mathrm{k}, \mathrm{nr}=$ number, $\mathrm{pf}=$ pfennig

Area: $\mathrm{G}=$ German Reich, $\mathrm{P}=$ Prussia, $\mathrm{Z} / \mathrm{G}=$ Zollverein/German Reich

Subfactors: $18=18$ series $1820-1913,93=93$ series $1840-1880$, Ind. $=31$ series heavy industries

Const. $=5$ series construction, Tex. $=29$ series textile industry, Agr. $=22$ series agriculture

Table 3: All series, subsets in colums. 


\section{SFB 649 Discussion Paper Series 2007}

For a complete list of Discussion Papers published by the SFB 649, please visit http://sfb649.wiwi.hu-berlin.de.

001 "Trade Liberalisation, Process and Product Innovation, and Relative Skill Demand" by Sebastian Braun, January 2007.

002 "Robust Risk Management. Accounting for Nonstationarity and Heavy Tails" by Ying Chen and Vladimir Spokoiny, January 2007.

003 "Explaining Asset Prices with External Habits and Wage Rigidities in a DSGE Model." by Harald Uhlig, January 2007.

004 "Volatility and Causality in Asia Pacific Financial Markets" by Enzo Weber, January 2007.

005 "Quantile Sieve Estimates For Time Series" by Jürgen Franke, JeanPierre Stockis and Joseph Tadjuidje, February 2007.

006 "Real Origins of the Great Depression: Monopolistic Competition, Union Power, and the American Business Cycle in the 1920s" by Monique Ebell and Albrecht Ritschl, February 2007.

007 "Rules, Discretion or Reputation? Monetary Policies and the Efficiency of Financial Markets in Germany, 14th to 16th Centuries" by Oliver Volckart, February 2007.

008 "Sectoral Transformation, Turbulence, and Labour Market Dynamics in Germany" by Ronald Bachmann and Michael C. Burda, February 2007.

009 "Union Wage Compression in a Right-to-Manage Model" by Thorsten Vogel, February 2007.

010 "On $\sigma$-additive robust representation of convex risk measures for unbounded financial positions in the presence of uncertainty about the market model" by Volker Krätschmer, March 2007.

011 "Media Coverage and Macroeconomic Information Processing" by Alexandra Niessen, March 2007.

012 "Are Correlations Constant Over Time? Application of the CC-TRIG to Return Series from Different Asset Classes." by Matthias Fischer, March 2007.

013 "Uncertain Paternity, Mating Market Failure, and the Institution of Marriage" by Dirk Bethmann and Michael Kvasnicka, March 2007.

014 "What Happened to the Transatlantic Capital Market Relations?" by Enzo Weber, March 2007.

015 "Who Leads Financial Markets?" by Enzo Weber, April 2007.

016 "Fiscal Policy Rules in Practice" by Andreas Thams, April 2007.

017 "Empirical Pricing Kernels and Investor Preferences" by Kai Detlefsen, Wolfgang Härdle and Rouslan Moro, April 2007.

018 "Simultaneous Causality in International Trade" by Enzo Weber, April 2007.

019 "Regional and Outward Economic Integration in South-East Asia" by Enzo Weber, April 2007.

020 "Computational Statistics and Data Visualization" by Antony Unwin, Chun-houh Chen and Wolfgang Härdle, April 2007.

021 "Ideology Without Ideologists" by Lydia Mechtenberg, April 2007.

022 "A Generalized ARFIMA Process with Markov-Switching Fractional Differencing Parameter" by Wen-Jen Tsay and Wolfgang Härdle, April 2007.

\section{SFB 649, Spandauer Straße 1, D-10178 Berlin} http:/ / sfb649.wiwi.hu-berlin.de 
023 "Time Series Modelling with Semiparametric Factor Dynamics" by Szymon Borak, Wolfgang Härdle, Enno Mammen and Byeong U. Park, April 2007.

024 "From Animal Baits to Investors' Preference: Estimating and Demixing of the Weight Function in Semiparametric Models for Biased Samples" by Ya'acov Ritov and Wolfgang Härdle, May 2007.

025 "Statistics of Risk Aversion" by Enzo Giacomini and Wolfgang Härdle, May 2007.

026 "Robust Optimal Control for a Consumption-Investment Problem" by Alexander Schied, May 2007.

027 "Long Memory Persistence in the Factor of Implied Volatility Dynamics" by Wolfgang Härdle and Julius Mungo, May 2007.

028 "Macroeconomic Policy in a Heterogeneous Monetary Union" by Oliver Grimm and Stefan Ried, May 2007.

029 "Comparison of Panel Cointegration Tests" by Deniz Dilan Karaman Örsal, May 2007.

030 "Robust Maximization of Consumption with Logarithmic Utility" by Daniel Hernández-Hernández and Alexander Schied, May 2007.

031 "Using Wiki to Build an E-learning System in Statistics in Arabic Language" by Taleb Ahmad, Wolfgang Härdle and Sigbert Klinke, May 2007.

032 "Visualization of Competitive Market Structure by Means of Choice Data" by Werner Kunz, May 2007.

033 "Does International Outsourcing Depress Union Wages? by Sebastian Braun and Juliane Scheffel, May 2007.

034 "A Note on the Effect of Outsourcing on Union Wages" by Sebastian Braun and Juliane Scheffel, May 2007.

035 "Estimating Probabilities of Default With Support Vector Machines" by Wolfgang Härdle, Rouslan Moro and Dorothea Schäfer, June 2007.

036 "Yxilon - A Client/Server Based Statistical Environment" by Wolfgang Härdle, Sigbert Klinke and Uwe Ziegenhagen, June 2007.

037 "Calibrating CAT Bonds for Mexican Earthquakes" by Wolfgang Härdle and Brenda López Cabrera, June 2007.

038 "Economic Integration and the Foreign Exchange" by Enzo Weber, June 2007.

039 "Tracking Down the Business Cycle: A Dynamic Factor Model For Germany 1820-1913" by Samad Sarferaz and Martin Uebele, June 2007.

\section{SFB 649, Spandauer Straße 1, D-10178 Berlin} http:/ / sfb649.wiwi.hu-berlin.de

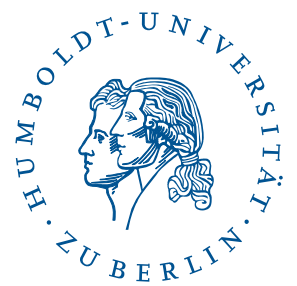

